REVIEW

\title{
High-value pleiotropic genes for developing multiple stress-tolerant biofortified crops for 21st-century challenges
}

\author{
Amjad M. Husaini iD ${ }^{1 凶}$ \\ (c) The Author(s), under exclusive licence to The Genetics Society 2022
}

\begin{abstract}
The agriculture-based livelihood systems that are already vulnerable due to multiple challenges face immediate risk of increased crop failures due to weather vagaries. As breeders and biotechnologists, our strategy is to advance and innovate breeding for weather-proofing crops. Plant stress tolerance is a genetically complex trait. Additionally, crops rarely face a single type of stress in isolation, and it is difficult for plants to deal with multiple stresses simultaneously. One of the most helpful approaches to creating stress-resilient crops is genome editing and trans- or cis-genesis. Out of hundreds of stress-responsive genes, many have been used to impart tolerance against a particular stress factor, while a few used in combination for gene pyramiding against multiple stresses. However, a better approach would be to use multi-role pleiotropic genes that enable plants to adapt to numerous environmental stresses simultaneously. Herein we attempt to integrate and present the scattered information published in the past three decades about these pleiotropic genes for crop improvement and remodeling future cropping systems. Research articles validating functional roles of genes in transgenic plants were used to create groups of multi-role pleiotropic genes that could be candidate genes for developing weather-proof crop varieties. These biotech crop varieties will help create 'high-value farms' to meet the goal of a sustainable increase in global food productivity and stabilize food prices by ensuring a fluctuation-free assured food supply. It could also help create a gene repository through artificial gene synthesis for 'resilient high-value food production' for the 21 st century.
\end{abstract}

Heredity (2022) 128:460-472; https://doi.org/10.1038/s41437-022-00500-w

With newer 21st century challenges, agriculture transition has become imperative for food and nutritional security in the new era. Farming currently faces formidable challenges in feeding a growing population in a sustainable way (Firbank et al. 2018). The situation has become complicated and worse in view of resource depletion, climate change, challenges due to pandemics like COVID-19. There is an immediate need to explore ways and means for developing a robust food production system that would survive the challenges of climate change, resource shrinkage and consumer preferences for nutritious food. In 2008, a High-Level Conference on World Food Security was convened by Food and Agricultural Organization, International Fund for Agricultural Development, United Nations World Food Programme and Consultative Group on International Agricultural Research. In this conference, 181 countries adopted a declaration that "It is essential to address the question of how to increase the resilience of present food production systems to challenges posed by climate change" (Husaini and Tuteja 2013). National Climate Assessment by the United States, Global Change Research Program has highlighted that climate change poses several challenges to crop production, and crop yields are expected to decrease due to altered temperatures and water availability, soil erosion, and pest and disease outbreaks (Reidmiller et al. 2018). According to the Global Report on Food Crises (GRFC 2020), a joint consensus-based assessment of acute food insecurity situations around the world by 16 partner organizations, weather extremes were the primary drivers of the acute food insecurity situation for almost 34 million people in 25 countries in 2019 in comparison with 29 million in 2018. Furthermore, the growing intensity and severity of these extreme weather events caused an increase in the number of people facing food crises in 2019 in comparison with 2018 (GRFC 2020). These extreme weather events are generally an amulgam of multiple stress types and are very complicated to handle.

\section{CROPS SELDOM EXPERIENCE SINGLE STRESS, AND STRESS TOLERANCE IS A COMPLEX TRAIT}

Crop plants often experience more than one biotic and abiotic stress (Hasanuzzaman et al. 2012) (Fig. 1). Stress tolerance is genetically complex, and since plants rarely face a single type of stress in isolation, it becomes difficult for a plant to deal with multiple stresses simultaneously (Husaini 2014). Stress tolerance results through an interplay of multiple genes. For example, multiple signaling cascades are used for broad-spectrum disease resistance. Induction of both salicylic acid (SA)-dependent and Jasmonic Acid /Ethylene-dependent defense response pathways may be required (Li et al. 2019). Specific genes can be employed to develop plants with tolerance to multiple pathogens and biotic stresses. (Chun et al. 2012) have demonstrated the critical

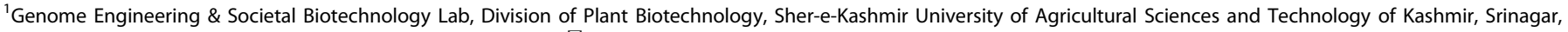
Jammu \& Kashmir 190025, India. Associate editor Chenwu Xu. ${ }^{凶}$ email: amjadhusaini@skuastkashmir.ac.in

Received: 28 November 2021 Revised: 5 January 2022 Accepted: 5 January 2022

Published online: 16 February 2022 


\section{Nutrient-dense stress-resilient crops possessing pleiotropic genes with multiple functional roles}

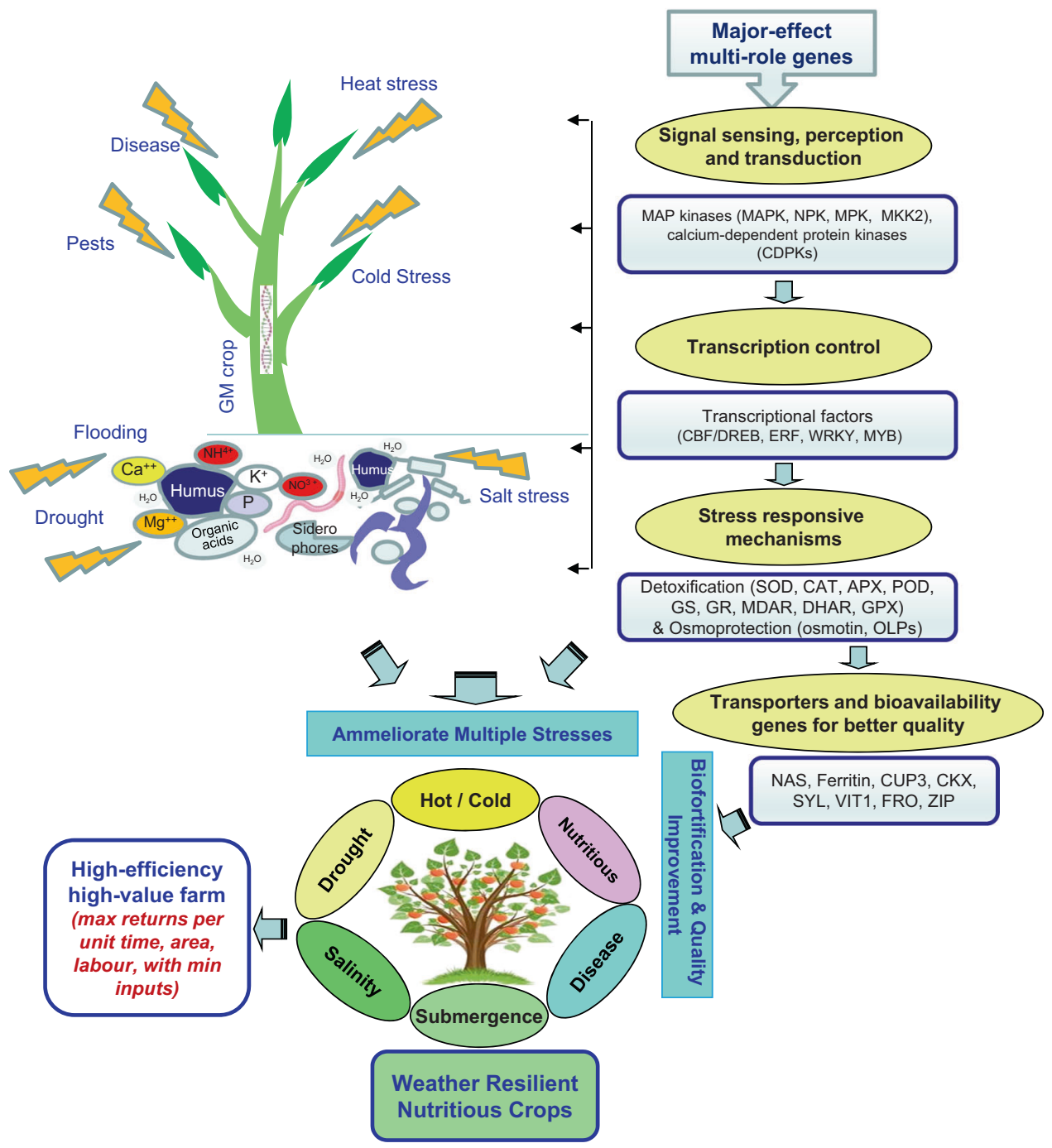

Fig. 1 An overview of the 21 st-century challenges and the high-value genes for breeding nutrient-dense weather-resilient crops. Crops can develop resilience towards stresses through genome engineering and increase uptake of nutrients through better nutrient use efficiency, and hence meet the food and nutritional security challenges. Such crops will support in establishing high-efficiency farms capable of giving better returns per unit of the applied input (time, space, labor, energy).

involvement of Nitric Oxide in both these pathways. Their study suggests that overexpression of Neuronal Nitric oxide synthase in Nicotiana tabacum can sufficiently induce both the JA/ETdependent pathway and the SA-dependent pathway and impart resistance against bacteria, fungi and viruses. Similarly, the overexpression of Arabidopsis thaliana Nonexpresser of PR GENES 1 (AtNPR1), a key regulator of broad-spectrum disease resistance (SAR), imparts resistance in Fragaria vesca L. against multiple pathogens. It imparts resistance against three fungal diseases (anthracnose caused by Colletotrichum acutatum, crown rot caused by $C$. gloeosporioides and powdery mildew caused by Podosphaera aphanis), and one bacterial disease viz. angular leaf spot caused by Xanthomonas fragariae (Silva et al. 2015). These diseases cause considerable losses in fruit ranging between 50 and $80 \%$.

This situation throws a big challenge to the food and nutritional security of the growing world population, which is projected to reach 9.7 billion by 2050 and will necessitate enhancement in agricultural production by at least $70-85 \%$ (Alexandratos and Bruinsma 2012), (Ray et al. 2013). However, the bright side is that there is impressive progress in plant biotechnology and the associated 'gene revolution' for crop improvement. The critical question is that can we mine biodiversity for food and nutritional security? (McCouch et al. 2013) suggested that the first step would be to obtain sequence information from the genomes of organisms to generate a 'parts list' that can help decipher mechanisms enabling plants to adapt to numerous environments and guide remodeling cropping systems for the future. There are arguably millions of traits in a complex organism such as the human, but the number of genes in the human genome is only about 20,000. Inevitably, there are at least some genes that affect multiple traits. The basic purpose of this paper is to provide a snapshot of this 'list' of candidate genes with critical roles that cause significant effects on the plant's phenotype, and can therefore be employed to develop biotech crops resilient to multiple stresses. 


\section{PLEIOTROPIC GENES FOR CROP IMPROVEMENT}

Pleiotropy is a phenomenon in which a single locus affects two or more distinct phenotypic traits. The term was formally introduced in 1910 by the German geneticist Ludwig Plate (Stearns 2010). Mendel too had described an early case of pleiotropy of three characters (seed coat color, flower color, and axial spots) in his classic 1866 paper (Stearns 2010), (Fairbanks and Rytting 2001). Pleiotropy cannot be treated as a unitary concept with a definable prevalence. It is a suite of conceptually related but empirically independent phenomena (Paaby and Rockman 2013). Many classifications that are not mutually exclusive have been proposed by different workers (Paaby and Rockman 2013), (Hodgkin 2002), (Solovieff et al. 2013), (Wagner and Zhang 2011). At its essence, pleiotropy implies a mapping from one thing at the genetic level to multiple things at a phenotypic level (Paaby and Rockman 2013). Pleiotropy is generally caused by a single molecular function involved in multiple biological processes (He and Zhang 2006). Characterizing the underlying biological mechanism of a pleiotropic effect is a major challenge in the field as many alternative models for an apparent cross-phenotype effect can fit the observed data (Solovieff et al. 2013).

A popular method of measuring pleiotropy is to use knock-out genotypes in a homogenous background (Dudley et al. 2005). By the same analogy, knock-in genotypes are used to validate the function of (trans)genes. In the last few decades, genetic modification (GM) techniques have been used to combine and modify genes from genetically distant individuals for conferring desired genetic traits on resultant biotech crops. The latest among these techniques focus on genome editing and include TALENand CRISPR-based methods like Cas-Clover, Crispr-Act3 (Abdallah et al. 2015; Xianghong et al. 2018; Luo et al. 2019; Pan et al. 2021; Roca Paixao et al. 2019). Even there is scope to use CRISPR-based knock-out strategy to downregulate those cis-regulatory elements which function as negative regulators of abiotic stress (Zafar et al. 2020).

Based on an in-depth perusal of earlier studies, we prepared a repository of pleitropic genes that should be the candidates for developing weather-resilient and nutrient-rich crop plants with inbuilt tolerance to multiple stresses. This review focuses on mining useful information about genes that promote abiotic stress tolerance (e.g. drought, salinity, submergence, cold, freezing and heat) and enhancing product quality. These 'high-value genes' can lay a strong foundation for a sustainable agricultural production model for assured food and nutritional security (Fig. 1). For the sake of brevity, we focused on the cross-phenotype 'effects' of the selected transgenes, without much discussion about the underlying mechanisms of their action as that would have been beyond the scope of a single review. The information presented below shall be very useful for biotechnologists and breeders for developing better crops. For understanding the individual mechanisms in detail, it is recommended to refer to the respective cited research paper(s).

\section{MAJOR-EFFECT MULTI-ROLE GENES FOR CHALLENGING SITUATIONS \\ Transgenes encoding ROS scavenger proteins}

Oxidative damage in plants is a consequence of exposure to temperature extremes, high light intensity, water stress, salinity, and mineral deficiencies. During oxidative stress, the balance between reactive oxygen species production and the quenching activity of the antioxidants is disturbed. Plants with high antioxidant levels, either constitutive or induced, have better resistance to this oxidative damage. There is a well-known correlation between stress tolerance and activities of the major antioxidative enzymes viz. superoxide dismutase (SOD), catalase (CAT), ascorbate peroxidise (APX), guaicol peroxidase, glutathione synthase and glutathione reductase (reviewed in (Hossain et al.
2011)). Experiments using transgenic plant models that overproduce these antioxidant enzymes provide clear evidence that their over-production enhances tolerance against osmotic stress, high temperature, oxidative stress, photooxidative, and ozone damage ((Husaini et al. 2010); (Kapoor et al. 2019); (Sun et al. 2020)) (Table 1). A perusal of the table shows that it has been nearly one and a half decades since discovering their ROS scavenging properties using transgenic approach. However, still, they have not been exploited commercially. Critical evaluation of these engineered alterations in the antioxidant system on crop productivity under normal and multiple stress environments in field conditions should be allowed by the regulatory agencies to successfully meet the challenges of the 21 st century.

\section{Transgenes encoding transcription factors}

Transcription factors play a significant role in controlling gene expression and activate the cascades of genes acting together. In order to impart tolerance against multiple stresses, a good strategy is to overexpress the transcription factor encoding genes that control stress-responsive multiple genes of various pathways. Some major families of transcription factors act under the influence of ethylene, jasmonic acid, SA, and other phytohormones, conferring abiotic stress tolerance.

Although much information about transcription factors has been gathered on their role in diverse abiotic stresses, selecting key TFs to develop abiotic stress-tolerant plants using transgenic technology is still an important issue before us (Wang et al. 2016). Based on the perusal of available literature related to many TF families (including WRKY, NF-Y, Zn-finger etc.), we propose using some selected transcription factors that have a proven role in imparting tolerance against multiple stresses simultaneously (Table 1).

AP2/Ethylene responsive element-binding proteins (EREBP) family includes a large group of plant-specific TFs. It is characterized by the presence of a highly conserved AP2/ ethylene-responsive element-binding factor (ERF) DNA-binding domain that directly interacts with GCC box and/or dehydrationresponsive element (DRE)/C-repeat element, cis-acting elements at the promoter of downstream target genes (Riechmann and Meyerowitz 1998). These AP2/EREBP TFs are grouped into four major subfamilies: $A P 2$ (Apetala2), RAV (related to $A B I 3 / N P 1), D R E B$ (dehydration-responsive element-binding protein), and $E R F$ (Sakuma et al. 2002), (Sharoni et al. 2011). We discuss the last two subfamilies as these are important for multiple stress tolerance.

(a) The Ethylene Responsive element-binding Factors: The ERF subfamily is the largest group of the AP2/EREBP TF family (Dietz et al. 2010) and functions in plant stress tolerance by regulating the stress-responsive genes through interacting with the cis-element GCC boxes with a core sequence of AGCCGCC (Ohme-Takagi and Shinshi 1995); (Hao et al. 1998). Ethylene Response Factor (ERF) gene imparts tolerance to multiple stress factors such as drought, salinity, cold, pathogens, etc. (Table 2). This is partly due to their involvement in hormonal signaling pathways like ethylene, JA, or SA (Liang et al. 2008). ERFs act as a key regulatory hub. These are involved in ethylene, jasmonate, abscisic acid $(A B A)$, and redox signaling in many abiotic stresses (Müller and Munné-Bosch 2015). When constitutively overexpressed in transgenic tobacco, ERF from tomato confers enhanced tolerance to salt and pathogens by activating the expression of pathogen-related genes (Wang et al. 2004). Similarly, transgenic lines of tobacco overexpressing Tsi1 showed enhanced salt tolerance and resistance to pathogens (Park et al. 2001). The expression of many Pathogenesis-related (PR) genes, like PR1, PR2, PR3, SAR8.2 and osmotin got activated even under unstressed conditions. Overexpression 
Table 1. Some representative examples of the overexpression of genes encoding enzymatic antioxidants in plants.

Gene

Superoxide dismutase (Cu/Zn SOD)

Superoxide dismutase (SiCSD) (Cu/ Zn SOD)

Superoxide dismutase + ascorbate peroxidase (Mn SOD + APX)

Superoxide dismutase + ascorbate peroxidase (Mn SOD + APX)

Ascorbate peroxidase (CAPX)

Ascorbate peroxidase (CAPX)

Ascorbate peroxidase (swpa4)

Ascorbate peroxidase (swpa4)

Monodehydro ascorbate reductase

(MDAR1)

Monodehydro ascorbate reductase (AeMDHAR)

Dehydro ascorbate reductase (DHAR)

Glutathione peroxidase (GPX)

Transgenic plant

Nicotiana tabacum

Oryza sativa

Nicotiana tabacum

Festuca arundinacea

Manihot esculentum

Lycopersicon esculentum

Nicotiana tabacum

Nicotiana tabacum

Arabidopsis thaliana

Nicotiana tabacum

Oryza sativa

Nicotiana tabacum

Nicotiana tabacum

Nicotiana tabacum

Arabidopsis thaliana

Nicotiana tabacum

Arabidopsis thaliana

Arabidopsis thaliana

\section{Response to abiotic stresses}

Enhanced tolerance to salt, water, PEG stresses

Transgenic plants were more tolerant to MV mediated oxidative stress, salinity stress and drought stress

Enhances tolerance to drought, cold and oxidative stress

$\mathrm{MV}, \mathrm{H}_{2} \mathrm{O}_{2}$, and $\mathrm{Cu}, \mathrm{Cd}$ and As tolerance

Enhances tolerance to oxidative and chilling stress

Enhanced tolerance to UV-B, heat, drought and chilling stresses

Enhances tolerance to drought, salt and oxidative stress

Enhanced tolerance to $\mathrm{MV}, \mathrm{H}_{2} \mathrm{O}_{2}, \mathrm{NaCl}$ and Mannitol

Enhances tolerance to oxidative stress and drought

Enhanced tolerance to Ozone, salt and PEG stress

Confers salt tolerance

\section{Drought and salt tolerance}

Ozone and drought tolerance

Enhanced tolerance to $\mathrm{MV}, \mathrm{H}_{2} \mathrm{O}_{2}$, low temperature and $\mathrm{NaCl}$ stress

Enhances tolerance to salt and drought

Enhanced tolerance to MV under moderate light intensity, chilling stress under high light intensity or salt stress

Enhanced tolerance to $\mathrm{H}_{2} \mathrm{O}_{2}$, Fe ions, MV, chilling, high salinity or drought stresses

Enhanced tolerance against Aluminium toxicity

\section{References}

Badawi et al. 2004; Prashanth et al. 2008;

(Zhang et al. 2017; Lee et al. 2007;

Xu et al. 2014;

Wang et al. 2005;

Wang et al. 2006;

Cao et al. 2017;

Kim et al. 2008;

Kim et al. 2021;

Eltayeb et al. 2007;

Sultana et al. 2012;

Eltayeb et al. 2007;

Ushimaru et al.

2006;

Kwon et al. 2003;

Hao et al. 2019;

Yoshimura et al.

2004;

Gaber et al. 2006;

Yin et al. 2017

Glutathione peroxidase (GPX)

It may be noted that there are some genes whose role in ROS scavenging was validated nearly 15 years back but are yet to be exploited commercially!

of GmERF3 imparted resistance against tobacco mosaic virus (TMV) and enhanced salinity and drought tolerance in tobacco (Zhang et al. 2009).

(b) Dehydration-Responsive Element-Binding Factors (DREB): DREBs are well-characterized transcription factors known to play an important role in regulating gene expression in response to abiotic stresses via $A B A$-independent and $A B A-$ dependent manner (Table 2). Overexpression of HvCBF4 from barley in rice activates fifteen rice genes and increases tolerance to drought, high-salinity, and low-temperature stresses without stunting growth (Oh et al. 2007). (Hsieh et al. 2002) reported improved drought, chilling and oxidative stress tolerance of tomato plants expressing Arabidopsis DREB1. Similarly, overexpression of DREB1 in Arabidopsis results in the activation of expression of many stress-tolerance genes and tolerance of the plant to drought, high salinity, and/or freezing is improved (JagloOttosen et al. 1998); (Liu et al. 1998). Overexpression of $D R E B 1 A$ and OsDREB1 in transgenic Arabidopsis and rice plants, respectively, impart increased tolerance to drought, high salinity and freezing stress (Kasuga et al. 1999); (Gilmour et al. 2000); (Ito et al. 2006). DREB1A induces the expression of stress-tolerance genes like kin1, rd29A, rd22, cor6.6, and cor15a (Park et al. 2001). In an interesting study in Arabidopsis, it has been reported that a cystatin gene (cysteine proteinase inhibitor) AtCYSa possesses dehydration-responsive element (DRE) and abscisic acid $(A B A)$-responsive element (ABRE) in its promoter region
(Zhang et al. 2008). In transgenic Arabidopsis and yeast, this characteristic made AtCYSa as a DREB1A and AREB target gene, and enhanced tolerance against salt, oxidative, drought, and cold stresses. GmDREB2 and OsDREB2A overexpression in transgenic plants enhance drought and salt tolerance (Chen et al. 2007); (Mallikarjuna et al. 2011). Overexpression of $Z m D R E B 2 A$ results in improved droughtstress tolerance and enhanced thermo tolerance, indicating that $Z m D R E B 2 A$ had a dual function of mediating the expression of genes responsive to both water and heat stress (Qin et al. 2007). Similarly, transgenic Arabidopsis plants overexpressing DREB2A show increased thermo tolerance, in addition to tolerance against water stress (Sakuma et al. 2006).

\section{Transgenes encoding protein kinases}

Perception and signaling pathways are vital components of an adaptive response for plants' survival under stress conditions. Mitogen-Activated Protein Kinases (MAPKs) are serine/threonine protein kinases, which phosphorylate several substrates involved in numerous plant cellular responses. They perform a vital role in signal transduction pathways. Various stresses like low temperature, wounding, high osmolarity, high salinity, and ROS serve as signals for activating the MAPK cascade. MAPK cascade is a crucial convergent point for cross-talk between different abiotic stress responses (Table 3). To elucidate, gene silencing and overexpression studies on GhRaf19, a Raf-like MAPKKK gene, revealed 
Table 2. Transcription factor coding genes useful for incorporating multiple stress tolerance in plants.

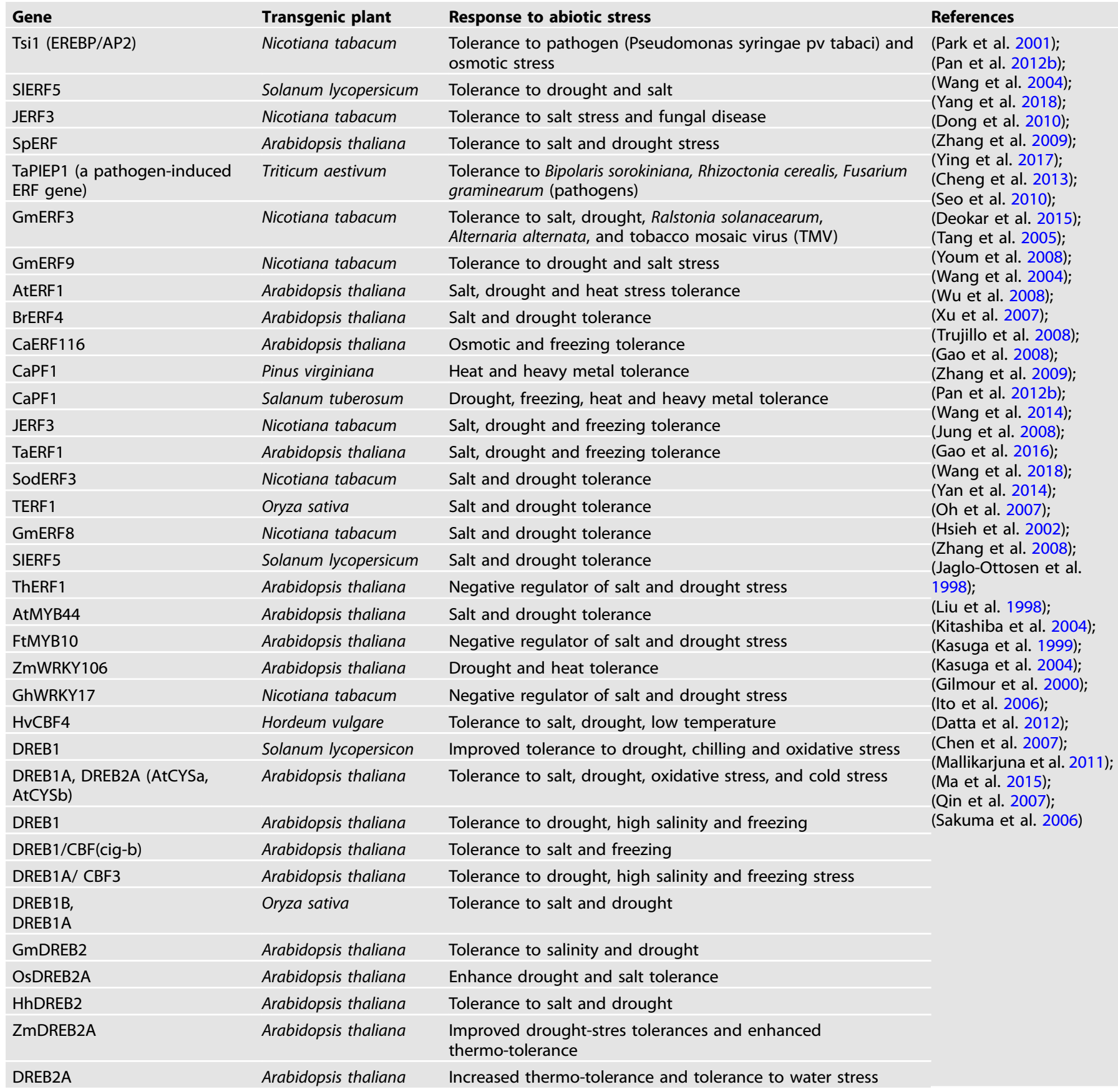

contrasting effects on drought, and salt stress as compared to cold stress (Jia et al. 2016). Virus-induced gene silencing of this gene in cotton and $N$. benthamiana enhanced tolerance against drought and salt stress, while its overexpression enhanced resistance against cold stress and vice versa. In transgenic maize, constitutive overexpression of MAPKKK/Nicotiana protein kinase 1 causes activation of an oxidative signal cascade. It results in higher photosynthetic rates in transgenics and tolerance to cold, heat, and salinity (Shou et al. 2004). Transgenic plants overexpressing Arabidopsis MAPK kinase 2 (MKK2) show tolerance against salt and freezing, while mkk2 null mutants are hypersensitive to salt and cold stress (Teige et al. 2004). MKK2 overexpression causes constitutive upregulation of 152 genes involved in stress signaling, metabolism, and transcriptional regulation. It also causes upregulation of the downstream MPK4, MPK6 activity in transgenic plants. Transgenic tobacco plants constitutively overexpressing NPK1 (an active tobacco ANP1 ortholog) possess better drought, salt, and cold tolerance than wild-type plants (Kovtun et al. 2000). OsMAPK5 overexpression in transgenic rice results in tolerance against salt stress and other abiotic stresses (Xiong and Yang 2003). ZmMPK17 overexpression in transgenic tobacco results in enhanced tolerance against osmotic stress, cold and viral pathogens (Pan et al. 2012a). Rice CDPK7 gene is a positive regulator in triggering salt/drought stress-responsive genes and has successfully imparted tolerance against cold, drought, and salinity stress in transgenic plants (Saijo et al. 2000) (Table 3). 
Table 3. Kinase genes useful for incorporating multiple stress tolerance in plants.

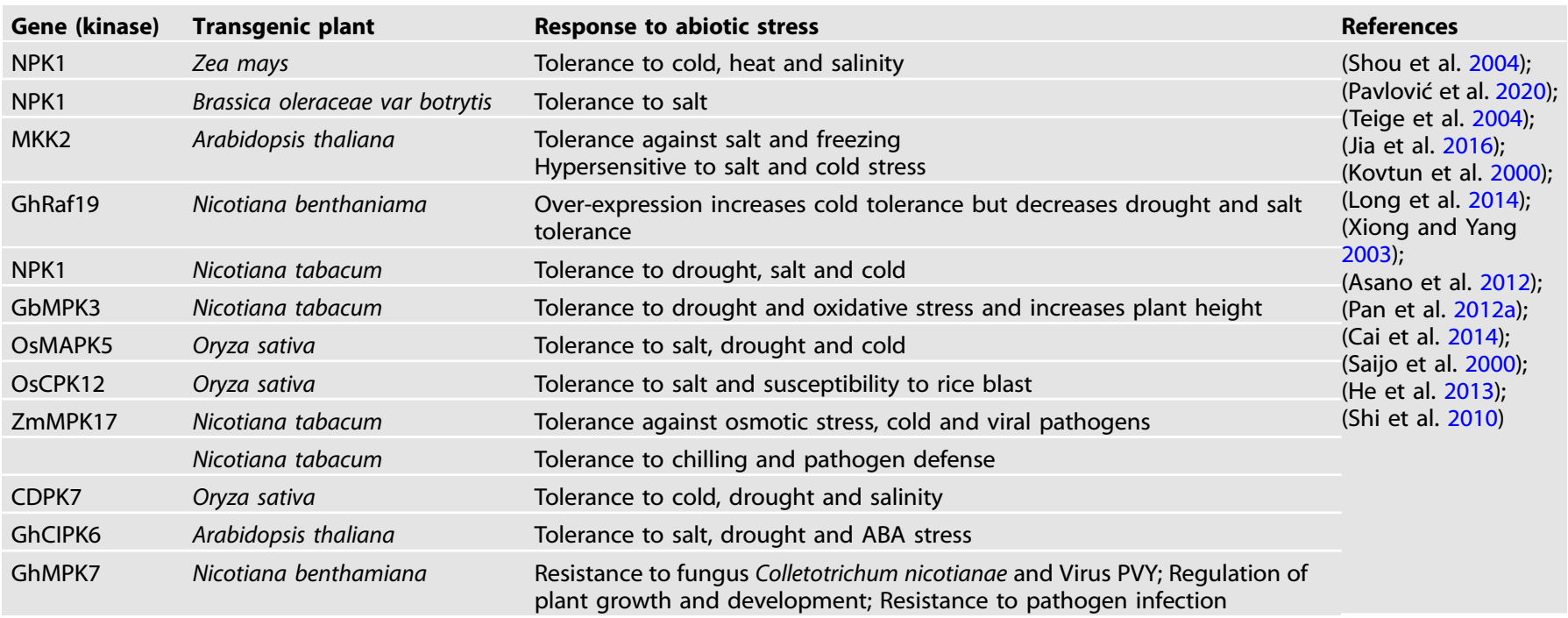

Table 4. Osmotin (PR-5 gene) gene is useful for incorporating multiple stress tolerance in plants.

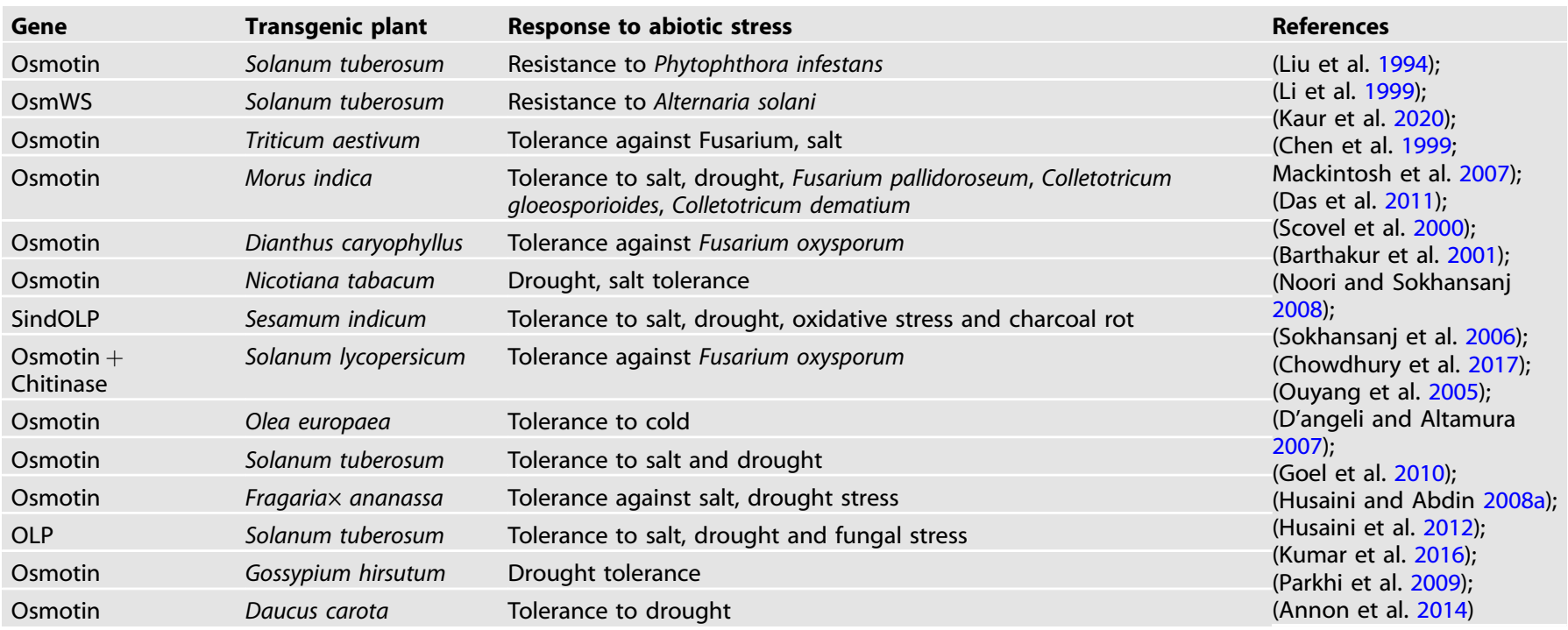

\section{Osmotin}

Osmotin is a cysteine-rich PR-5c protein. It was discovered as a thaumatin-like stress-responsive protein synthesized and accumulated by tobacco cells under salt and desiccation stress (Singh et al. 1985). It plays a major role in protecting plant plasma membranes under low plant water potential (Viktorova et al. 2012). It gets accumulated in plants under prolonged exposure to cold also (D'angeli and Altamura 2007), and its expression is also induced by $S A, A B A$, auxin, UV light, wounding, fungal infection, oomycetes, bacteria, and viruses (Fagoaga et al. 2001); (Anil Kumar et al. 2015); reviewed in (Husaini et al. 2011); (Husaini and Neri 2016).

There are numerous reports which show that osmotin and its homologs impart: (a) salt tolerance (Singh et al. 1987, 1985); (Bol et al. 1990) ; (Zhu et al. 1993), 1995; (Barthakur et al. 2001); (Sokhansanj et al. 2006); (Husaini and Abdin 2008a); (Goel et al. 2010), (b) drought tolerance (Barthakur et al. 2001); (Parkhi et al. 2009); (Sokhansanj et al. 2006); (Husaini and Abdin 2008b); (Goel et al. 2010), (c) cold tolerance (D'angeli and Altamura 2007), (d) and protection from fungal pathogens too (Raghothama et al. 1993); (Liu et al. 1994); (Abad et al. 1996); (Scovel et al. 2000); (Ramos et al. 2015), (Xue et al. 2016) ; (Sripriya et al. 2017). Osmotin from the resurrection plant Tripogon loliiformis has been used to confer tolerance to multiple abiotic stresses simultaneously (cold, drought, and salinity) in transgenic rice (Le et al. 2018). Taken together, osmotin could be useful in developing biotic and abiotic stress-tolerant genetically engineered plants (reviewed in (Husaini and Rafiqi 2012), (Husaini and Neri 2016)) (Table 4).

\section{GENES FOR MINERAL (IRON, ZINC, COPPER) BIOFORTIFICATION}

Mineral deficiency in human beings is a grave global challenge (Singh et al. 2010). Approaches like diet diversification, supplementation through minerals, fortification of food items and biofortification are used to address the issue. Application of mineral micro- and macro- nutrients coupled with breeding 
varieties with enhanced uptake of mineral elements, is a good strategy for biofortification of edible crops (Graham et al. 2001) (Graham et al. 2007); (Bouis 2000; Bouis et al. 2003); (Genc et al. 2005); (White and Broadley 2005) (Pfeiffer and McClafferty 2007). An important consideration is that these elements must be bioavailable to humans so that the gut absorbs them during the process of digestion and assimilation. The use of transgenic plants for increasing the micronutrients in staple food crops is a promising approach. Iron content in rice seeds can be enhanced by overexpression of nicotianamine synthase (NAS) gene, catalyzing the trimerisation of S-adenosyl methionine to form nicotianamine (NA) and nicotianamine aminotransferase (Bashir et al. 2006); (Haydon and Cobbett 2007); (Kim et al. 2006). Overexpression of NAS increases the secretion of phytosiderophores and the uptake of iron. NA chelates $\mathrm{Fe}$ (II) and $\mathrm{Fe}$ (III) cations, and plays an important role in its translocation and homeostasis(Takahashi et al. 2001); (Koike et al. 2004). Iron is transported from the cytoplasm into the plastid by a permease in chloroplasts 1 (Duy et al. 2007). It gets associated with ferritin, an iron-storage protein located in the plastid (Briat et al. 1999); (Petit et al. 2001). In transgenic rice, the combined expression of Pvferritin and AtNAS1 has been shown to cause a six-fold increase in iron content in the endosperm. Phytase does not prevent this iron accumulation, but on the contrary helps reduce the iron anti-nutrient phytate. Hence, it can be concluded that the overexpression of NAS and ferritin in transgenic plants can increase metal translocation to seeds. Another approach is to knock-out genes involved in the biosynthetic pathway of phytate in crops, thereby increasing the bioavailability of iron and zinc to human beings. This approach has been successful in rice and wheat, where low phytate varieties were developed using RNAi or CRISPR-Cas mediated knockdown of Inositol 1,3,4,5,6-pentakisphosphate 2-kinase (IPK1) gene (Ali et al. 2013), (Aggarwal et al. 2018), (Ibrahim et al. 2021).

In soil, mineral availability is influenced by its $\mathrm{pH}$, cation exchange capacity, redox conditions, microbial activity, water content, soil structure, and organic matter content (Shuman 1998); (Frossard et al. 2000). Fe, Zn, Cu, Ca and Mg in their cationic forms can be taken up by roots of all plant species, while $\mathrm{Fe}, \mathrm{Zn}$ and $\mathrm{Cu}$ can be taken up by graminaceous species as metal-chelates too. $\mathrm{Fe}, \mathrm{Zn}$ and $\mathrm{Cu}$ phytoavailability is generally enhanced in the rhizosphere of crops by the exudation of protons, siderophores and organic acids by roots (Hoffland et al. 2006); (Ismail et al. 2007); (Degryse et al. 2008).

Plants use two strategies for uptake of iron from the soil (Grotz and Guerinot 2006); (Puig et al. 2007). In non-graminaceous species, roots secrete organic acids and phenolic compounds to acidify the rhizosphere and enhance $\mathrm{Fe}^{3+}$ concentration in the soil. $\mathrm{Fe}^{3+}$ gets chelated to these compounds and is subsequently reduced by ferric reductases to $\mathrm{Fe}^{2+}$ in the root epidermis (Robinson et al. 1999); (Wu et al. 2005); (Mukherjee et al. 2006). Then zinc-regulated transporter and iron-regulated transporter (IRT) mediate $\mathrm{Fe}^{2+}$ influx to root cells (Ishimaru et al. 2006; Vert et al. 2002). In the second strategy, employed by cereals and grasses, phytosiderophores are secreated to chelate $\mathrm{Fe}^{3+}$, and the $\mathrm{Fe}^{3+}$-phytosiderophore complex is taken up by root cells (Ishimaru et al. 2006; von Wirén et al. 1995).

\section{Yellow stripe like (YSLs) proteins}

Maize yellow stripe 1 (YS1) protein belongs to the oligopeptide transporter (OPT) family and is a proton-coupled metal-complex symporter (Schaaf et al. 2004). Its homologues play a vital role in the uptake of $\mathrm{Fe}^{3+}$-phytosiderophore by graminaceous species (strategy II plants) (Haydon and Cobbett 2007; Ishimaru et al. 2006; Puig et al. 2007). YSL proteins and associated OPTs load and unload $\mathrm{Fe}^{2+}$-nicotianamine ( $\mathrm{Fe}^{2+}-\mathrm{NA}$ ) complexes into and out of the phloem for iron relocation within the plant. OsYSL2 is an Fe (II)- NA and Mn(II)- NA transporter involved in the phloem transport of both iron and manganese in rice (Koike et al. 2004).

Furthermore, the YSL proteins catalyze the uptake of $\mathrm{Zn}$ phytosiderophore complexes in graminaceous plant species (strategy II plants) (Haydon and Cobbett 2007; Suzuki et al. 2006; von Wirén et al. 1996). Although some $\mathrm{Ca}^{2+}$ channels in the plasma membrane are permeable to $\mathrm{Zn}^{2+}$ (Demidchik et al. 2002; White et al. 2002), however, most of the $\mathrm{Zn}^{2+}$ influx into the cytoplasm is facilitated by ZIPs (Assunção et al. 2001; Broadley et al. 2007; Colangelo and Guerinot 2006; Lopez-Millan et al. 2004; Palmgren et al. 2008; Pence et al. 2000). ZIP family mediates $\mathrm{Zn}^{2+}$ influx into the leaf cells (Ishimaru et al. 2005). YSL proteins load zinc into the phloem, where it is transported as a $\mathrm{Zn}$-NA complex to the sink tissues (Gross et al. 2003; Haydon and Cobbett 2007; Krüger et al. 2002; Puig et al. 2007; Waters and Grusak 2008). Interestingly, plants that hyper-accumulate $\mathrm{Zn}$ exhibit constitutively high expression of genes encoding ZIPs, YSL proteins and NAS.

YSL protein has been shown to play a vital role in loading $\mathrm{Cu}$ into the phloem, which is then transported as Cu- NA complex (Mira et al. 2001) (DiDonato et al. 2004; Guo et al. 2003; Puig et al. 2007); (Waters and Grusak 2008). Interestingly, the YSL proteins transport both $\mathrm{Cu}-\mathrm{NA}$ complexes and the free $\mathrm{Cu}^{2+}$ and $\mathrm{Fe}^{2+}$ cations (Wintz et al. 2003).

The above research findings clearly show that overexpression of YSL and NAS may increase metal uptake and translocation, especially iron, zinc, manganese and copper in transgenic plants. Such studies need to be undertaken to address the grave problems of mineral malnutrition in women and children. Various genes play a vital role in biofortification (Table 5). However, there is a need to identify many more candidate genes that can impart gain-of-function attributes to genetically engineered crops. Based on the available literature, a set of few such candidate genes is presented in Table 6.

\section{CONSTRAINTS AND CHALLENGES \\ Biopolitics around GM crops}

The most successful crop breeding project was the incorporation of semidwarf genes to create the modern high-yielding varieties

Table 5. Genes useful for biofortification through mobilisation of multiple nutrients and enhancement of physiological parameters in plants.

\begin{tabular}{|c|c|c|c|}
\hline Gene & Transgenic Plant & Response & References \\
\hline $\begin{array}{l}\text { Suppression of DET1 (De-etiolated } \\
\text { 1) by RNAi }\end{array}$ & Solanum lycopersicum & $\begin{array}{l}\text { Improves both carotenoid as well as flavonoid content } \\
\text { simultaneously }\end{array}$ & \multirow{4}{*}{$\begin{array}{l}\text { (Davuluri et al. 2005); } \\
\text { (Wirth et al. 2009); } \\
\text { (Song et al. 2014); } \\
\text { (Ramireddy et al. } \\
\text { 2018) }\end{array}$} \\
\hline $\begin{array}{l}\text { NAS (Nicotianamine synthase) and } \\
\text { ferritin }\end{array}$ & Oryza sativa & Increase in mineral content of $\mathrm{Fe}$ and $\mathrm{Zn}$ & \\
\hline $\begin{array}{l}\text { Alternanthera philoxeroides KUP3 } \\
\text { (ApKUP3) }\end{array}$ & Oryza sativa & $\begin{array}{l}\text { Enhanced } \mathrm{K}^{+} \text {nutrition and drought tolerance in transgenic } \\
\text { plants. } \\
\text { Increased the net photosynthetic rate, activities of superoxide } \\
\text { dismutase, peroxidase, and ascorbate peroxidase. }\end{array}$ & \\
\hline $\begin{array}{l}\text { Cytokinin oxidase / dehydrogenase } \\
\text { gene (CKX) }\end{array}$ & Hordeum vulgare & $\begin{array}{l}\text { Improved nutrient efficiency, and biofortification. } \\
\text { Improved tolerance against drought }\end{array}$ & \\
\hline
\end{tabular}


Table 6. Some important genes for conferring traits beneficial for better crops.

\begin{tabular}{|c|c|c|}
\hline Trait & Gene & References \\
\hline \multirow[t]{6}{*}{ Bioavailability } & Phytate degradation (Phytase) & \multirow{6}{*}{$\begin{array}{l}\text { (White and Broadley 2009); } \\
\text { (Bouis 2000); } \\
\text { (Devappa et al. 2012); } \\
\text { (Shewry and Ward 2012); } \\
\text { (Shi et al. 2005); } \\
\text { (Brinch-Pedersen et al. 2002); } \\
\text { (Matuschek et al. 2001); } \\
\text { (Shi et al. 2005); } \\
\text { (Lucca et al. 2001); } \\
\text { (Chen et al. 2003); } \\
\text { (Caimi et al. 1996); } \\
\text { (Ali et al. 2013); } \\
\text { (Aggarwal et al. 2018); } \\
\text { (Ibrahim et al. 2021) }\end{array}$} \\
\hline & Phytate biosynthesis (MIK) & \\
\hline & Cysteine synthesis (rgMT) & \\
\hline & Vitamin synthesis (DHAR) & \\
\hline & Inulin biosynthesis (SacB) & \\
\hline & $\begin{array}{l}\text { Inositol 1,3,4,5,6-pentakisphosphate } \\
\text { 2-kinase (IPK1) }\end{array}$ & \\
\hline \multirow[t]{3}{*}{ Seed filling } & $\begin{array}{l}\text { Mineral transporters for phloem unloading } \\
\text { (YSL, HMA, Nramp) }\end{array}$ & \multirow{3}{*}{$\begin{array}{l}\text { (Chu et al. 2010); } \\
\text { (Jean et al. 2005); } \\
\text { (Tauris et al. 2009); } \\
\text { (Liao et al. 2012); } \\
\text { (Lucca et al. 2001); } \\
\text { (Goto et al. 2000); } \\
\text { (Vasconcelos et al. 2003); } \\
\text { (Murray-Kolb et al. 2002); } \\
\text { (Lanquar et al. 2005); } \\
\text { (Kim et al. 2006) }\end{array}$} \\
\hline & Nutrient storage proteins (ferritin, glutelin) & \\
\hline & Vacuole Fe loading (VIT1, Nramp3, Nramp4) & \\
\hline \multirow[t]{2}{*}{ Shoot transport } & $\begin{array}{l}\text { Mineral transporters for xylem unloading \& } \\
\text { phloem loading (FRO, ZIP, COPT) }\end{array}$ & \multirow{2}{*}{$\begin{array}{l}\text { (Wu et al. 2005); } \\
\text { (Bughio et al. 2002); } \\
\text { (Cohen et al. 2004); } \\
\text { (Eckhardt et al. 2001); } \\
\text { (Wintz et al. 2003); } \\
\text { (Tauris et al. 2009); } \\
\text { (del Pozo et al. 2010); } \\
\text { (Chu et al. 2010); } \\
\text { (Jean et al. 2005); } \\
\text { (Tauris et al. 2009) }\end{array}$} \\
\hline & $\begin{array}{l}\text { Mineral phloem mobility: increased synthesis of } \\
\text { mineral chelators such as ITP or NA (YSL, OPT) }\end{array}$ & \\
\hline \multirow[t]{4}{*}{ Root uptake \& xylem loading } & $\begin{array}{l}\text { Mineral transporters (IRT, ZIP, YS, IREG, HMA, } \\
\text { FRD3, MTP3) }\end{array}$ & \multirow{4}{*}{$\begin{array}{l}\text { (Wong and Cobbett 2009); } \\
\text { (Arrivault et al. 2006); } \\
\text { (Durrett et al. 2007); } \\
\text { (Green and Rogers 2004); } \\
\text { (Tauris et al. 2009); } \\
\text { (Wu et al. 2005); } \\
\text { (Durrett et al. 2007); } \\
\text { (Green and Rogers 2004) }\end{array}$} \\
\hline & Phytosiderophore secretion (YS, NAS) & \\
\hline & Soil nutrient availability (FRO) & \\
\hline & Organic acid release (FRD3) & \\
\hline
\end{tabular}

that began with the release of IR8 60 years ago, spurring the Green Revolution in rice (Zeigler 2007). Production of 'Golden Rice' was another significant advancement and involved the transfer of genes necessary for the accumulation of carotenoids (vitamin A precursors) in the rice endosperm (Ye et al. 2000) ; (Potrykus 2003). It resulted in about $140 \mathrm{~g}$ of the rice providing a child's RDA for beta carotene (Raney and Pingali 2007) and has been shown to get efficiently converted to vitamin A in humans (Tang et al. 2009). GM crops have not met their full potential to deliver practical solutions to end-users, especially in developing countries. There was a report way back in 2001, wherein the European Commission confirmed the safety of GM crops and food, after painstaking research spanning $15 \mathrm{y}$ and involving 81 projects with 400 scientists. Even the former founder of Greenpeace, Dr. Patrick Moore criticized Greenpeace as committing a "crime against humanity" for its opposition to GM Golden Rice. Further, 107 Nobel Laureates urged Greenpeace and its supporters to "abandon their campaign against 'GMOs' in general and Golden Rice in particular". However, golden rice has still not seen the light of the day, courtesy of biopolitics! A recent silver lining in the dark cloud is that the Philippines has recently in July 2021 approved the commercial production of golden rice and has become the first country to do so.

\section{Costly regulatory regime favors multi-national companies}

Despite promising research results of genetically modified crops with beneficial agronomic traits like enhanced drought tolerance, salt tolerance and insect resistance, developed by publicly funded research, these have not reached end users because of the extremely high cost of regulatory compliance. Besides political, socioeconomic, cultural, and ethical concerns about modern biotech crops related to the fear of technological "neocolonialism" in developing countries, intellectual property rights, land ownership, customer choices, negative cultural and religious perceptions, and 'fear of the unknown' have impeded the spread of these crops. Such public concerns fueled and supported by vested interests have led to the over-regulation of this technology, threatening to retard its applications in agriculture reviewed in (Husaini and Tuteja 2013). It is estimated that it costs up to US\$20 million to gain commercial certification of a single GM crop. 1st World Food Prize Winner Professor M.S. Swaminathan has pitched for promoting more public-sector research in GM technology so that there can be inclusiveness in access to technology (Husaini and Sohail 2018). It is high time that political will be shown to develop GM Crops in the public sector, as a complicated and costly regulatory regime is a blessing in disguise for MNCs! 


\section{CONCLUSION}

Agriculture is central to food and nutritional security as well as the general wellbeing of a majority population. Evolving resilient, holistic, and secure food systems that adapt to climate change and other stress factors is indispensable for human survival in the 21 st century. Here, we demonstrate the role of major-effect multirole pleiotropic genes in imparting tolerance against multiple stresses per se or through modulation of regulatory pathways. The crops engineered using these genes can help better adopt resource conservation technologies, which are beneficial for environmental sustainability. These crops will possess better nutritional value, higher nitrogen and water use efficiencies, disease and pest tolerance, and can withstand water scarcity, flooding, high temperature, cold weather, salinity, mineral toxicity, etc. In addition to reducing carbon emissions by reducing fuel consumption, these can help in carbon sequestration too. In the future, biotech crops will be developed using genome engineering of these pleiotropic genes. They can even be synthesized artificially and pyramided to combat problems involving highly complex traits. To create a resilient high-value crop repertoire for 'High-Value Farms', these genes will be an indispensable asset.

\section{REFERENCES}

Abad LR, D'Urzo MP, Liu D, Narasimhan ML, Reuveni M, Zhu JK et al. (1996) Antifungal activity of tobacco osmotin has specificity and involves plasma membrane permeabilization. Plant Sci 118(1):11-23

Abdallah NA, Prakash CS, McHughen AG (2015) Genome editing for crop improvement: challenges and opportunities. GM Crops Food 6(4):183-205

Aggarwal S, Kumar A, Bhati KK, Kaur G, Shukla V, Tiwari S et al. (2018) RNAi-mediated downregulation of inositol pentakisphosphate kinase (IPK1) in wheat grains decreases phytic acid levels and increases Fe and $\mathrm{Zn}$ accumulation. Front Plant Sci 9:259

Alexandratos N, Bruinsma J (2012) World Agriculture towards 2030/2050: The 2012 Revision. ESA Working Paper No. 12-03, FAO, Rome.

Ali N, Paul S, Gayen D, Sarkar SN, Datta K, Datta SK (2013) Development of low phytate rice by RNAi mediated seed-specific silencing of inositol 1, 3, 4, 5, 6-pentakisphosphate 2-kinase gene (IPK1). PloS ONE 8(7):e68161

Anil Kumar S, Hima Kumari P, Shravan Kumar G, Mohanalatha C, Kavi Kishor P (2015) Osmotin: a plant sentinel and a possible agonist of mammalian adiponectin. Front Plant Sci 6:163

Annon A, Rathore K, Crosby K (2014) Overexpression of a tobacco osmotin gene in carrot (Daucus carota L.) enhances drought tolerance. Vitr Cell Dev Biol-Plant 50 (3):299-306

Arrivault S, Senger T, Krämer U (2006) The Arabidopsis metal tolerance protein AtMTP3 maintains metal homeostasis by mediating $\mathrm{Zn}$ exclusion from the shoot under Fe deficiency and Zn oversupply. Plant J 46(5):861-879

Asano T, Hayashi N, Kobayashi M, Aoki N, Miyao A, Mitsuhara I et al. (2012) A rice calcium-dependent protein kinase OsCPK12 oppositely modulates salt-stress tolerance and blast disease resistance. Plant J 69(1):26-36

Assunção A, Martins PDC, De Folter S, Vooijs R, Schat H, Aarts M (2001) Elevated expression of metal transporter genes in three accessions of the metal hyperaccumulator Thlaspi caerulescens. Plant, Cell Environ 24(2):217-226

Badawi GH, Yamauchi Y, Shimada E, Sasaki R, Kawano N, Tanaka K et al. (2004) Enhanced tolerance to salt stress and water deficit by overexpressing superoxide dismutase in tobacco (Nicotiana tabacum) chloroplasts. Plant Sci 166 (4):919-928

Barthakur S, Babu V, Bansa K (2001) Over-expression of osmotin induces proline accumulation and confers tolerance to osmotic stress in transgenic tobacco. J Plant Biochem Biotechnol 10(1):31-37

Bashir K, Inoue H, Nagasaka S, Takahashi M, Nakanishi H, Mori S et al. (2006) Cloning and characterization of deoxymugineic acid synthase genes from graminaceous plants. J Biol Chem 281(43):32395-32402

Bol J, Linthorst H, Cornelissen B (1990) Plant pathogenesis-related proteins induced by virus infection. Annu Rev Phytopathol 28(1):113-138

Bouis HE (2000) Enrichment of food staples through plant breeding: a new strategy for fighting micronutrient malnutrition. Nutrition 16(7-8):701-704

Bouis HE, Chassy BM, Ochanda JO (2003) 2. Genetically modified food crops and their contribution to human nutrition and food quality. Trends Food Sci Technol 14 (5-8):191-209

Briat J-F, Lobreaux S, Grignon N, Vansuyt G (1999) Regulation of plant ferritin synthesis: how and why. Cell Mol Life Sci CMLS 56(1):155-166
Brinch-Pedersen H, Sørensen LD, Holm PB (2002) Engineering crop plants: getting a handle on phosphate. Trends Plant Sci 7(3):118-125

Broadley MR, White PJ, Hammond JP, Zelko I, Lux A (2007) Zinc in plants. N. Phytologist 173(4):677-702

Bughio N, Yamaguchi H, Nishizawa NK, Nakanishi H, Mori S(2002) Cloning an ironregulated metal transporter from rice J Exp Bot 53(374):1677-1682

Cai G, Wang G, Wang L, Pan J, Liu Y, Li D (2014) ZmMKK1, a novel group A mitogenactivated protein kinase kinase gene in maize, conferred chilling stress tolerance and was involved in pathogen defense in transgenic tobacco. Plant Sci 214:57-73

Caimi PG, McCole LM, Klein TM, Kerr PS (1996) Fructan accumulation and sucrose metabolism in transgenic maize endosperm expressing a Bacillus amyloliquefaciens SacB gene. Plant Physiol 110(2):355-363

Cao S, Du X-H, Li L-H, Liu Y-D, Zhang L, Pan X et al. (2017) Overexpression of Populus tomentosa cytosolic ascorbate peroxidase enhances abiotic stress tolerance in tobacco plants. Russian J Plant Physiol 64(2):224-234

Chen M, Wang Q-Y, Cheng X-G, Xu Z-S, Li L-C, Ye X-G et al. (2007) GmDREB2, a soybean DRE-binding transcription factor, conferred drought and high-salt tolerance in transgenic plants. Biochem Biophys Res Commun 353 (2):299-305

Chen W, Chen P, Liu D, Kynast R, Friebe B, Velazhahan R et al. (1999) Development of wheat scab symptoms is delayed in transgenic wheat plants that constitutively express a rice thaumatin-like protein gene. Theor Appl Genet 99(5):755-760

Chen Z, Young TE, Ling J, Chang S-C, Gallie DR (2003) Increasing vitamin C content of plants through enhanced ascorbate recycling. Proc Natl Acad Sci 100 (6):3525-3530

Cheng M-C, Liao P-M, Kuo W-W, Lin T-P (2013) The Arabidopsis ETHYLENE RESPONSE FACTOR1 regulates abiotic stress-responsive gene expression by binding to different cis-acting elements in response to different stress signals. Plant Physiol 162(3):1566-1582

Chowdhury S, Basu A, Kundu S (2017) Overexpression of a new osmotin-like protein gene (SindOLP) confers tolerance against biotic and abiotic stresses in sesame. Front Plant Sci 8:410

Chu H-H, Chiecko J, Punshon T, Lanzirotti A, Lahner B, Salt DE et al. (2010) Successful reproduction requires the function of Arabidopsis Yellow Stripe-Like1 and Yellow Stripe-Like3 metal-nicotianamine transporters in both vegetative and reproductive structures. Plant Physiol 154(1):197-210

Chun HJ, Park HC, Koo SC, Lee JH, Park CY, Choi MS et al. (2012) Constitutive expression of mammalian nitric oxide synthase in tobacco plants triggers disease resistance to pathogens. Mol Cells 34(5):463-471

Cohen CK, Garvin DF, Kochian LV (2004) Kinetic properties of a micronutrient transporter from Pisum sativum indicate a primary function in Fe uptake from the soil. Planta 218(5):784-792

Colangelo EP, Guerinot ML (2006) Put the metal to the petal: metal uptake and transport throughout plants. Curr Opin Plant Biol 9(3):322-330

D'angeli S, Altamura M (2007) Osmotin induces cold protection in olive trees by affecting programmed cell death and cytoskeleton organization. Planta 225 (5):1147-1163

Das M, Chauhan H, Chhibbar A, Haq QMR, Khurana P (2011) High-efficiency transformation and selective tolerance against biotic and abiotic stress in mulberry, Morus indica cv. K2, by constitutive and inducible expression of tobacco osmotin. Transgenic Res. 20(2):231-246

Datta K, Baisakh N, Ganguly M, Krishnan S, Yamaguchi Shinozaki K, Datta SK (2012) Overexpression of Arabidopsis and rice stress genes' inducible transcription factor confers drought and salinity tolerance to rice. Plant Biotechnol J 10 (5):579-586

Davuluri GR, Van Tuinen A, Fraser PD, Manfredonia A, Newman R, Burgess D et al. (2005) Fruit-specific RNAi-mediated suppression of DET1 enhances carotenoid and flavonoid content in tomatoes. Nat Biotechnol 23(7):890-895

Degryse F, Verma V, Smolders E (2008) Mobilization of Cu and Zn by root exudates of dicotyledonous plants in resin-buffered solutions and in soil. Plant Soil 306 (1):69-84

Demidchik V, Bowen HC, Maathuis FJ, Shabala SN, Tester MA, White PJ et al. (2002) Arabidopsis thaliana root non-selective cation channels mediate calcium uptake and are involved in growth. Plant J 32(5):799-808

Deokar AA, Kondawar V, Kohli D, Aslam M, Jain PK, Karuppayil SM et al. (2015) The CarERF genes in chickpea (Cicer arietinum L.) and the identification of CarERF116 as abiotic stress responsive transcription factor. Funct Integr Genomics 15(1):27-46

Devappa RK, Makkar HP, Becker K (2012) Localisation of antinutrients and qualitative identification of toxic components in Jatropha curcas seed. J Sci Food Agric 92 (7):1519-1525

del Pozo T, Cambiazo V, González M (2010) Gene expression profiling analysis of copper homeostasis in Arabidopsis thaliana. Biochem Biophys Res. Commun 393(2):248-252 
DiDonato Jr RJ, Roberts LA, Sanderson T, Eisley RB, Walker EL (2004) Arabidopsis Yellow Stripe-Like2 (YSL2): a metal-regulated gene encoding a plasma membrane transporter of nicotianamine-metal complexes. Plant J 39(3):403-414

Dietz K-J, Vogel MO, Viehhauser A (2010) AP2/EREBP transcription factors are part of gene regulatory networks and integrate metabolic, hormonal and environmental signals in stress acclimation and retrograde signalling. Protoplasma 245 (1):3-14

Dong N, Liu X, Lu Y, Du L, Xu H, Liu H et al. (2010) Overexpression of TaPIEP1, a pathogen-induced ERF gene of wheat, confers host-enhanced resistance to fungal pathogen Bipolaris sorokiniana. Funct Integr Genomics 10(2):215-226

Dudley AM, Janse DM, Tanay A, Shamir R, Church GM (2005) A global view of pleiotropy and phenotypically derived gene function in yeast. Mol Syst Biol 1 (1):2005.0001

Durrett TP, Gassmann W, Rogers EE (2007) The FRD3-mediated efflux of citrate into the root vasculature is necessary for efficient iron translocation. Plant Physiol 144(1):197-205

Duy D, Wanner G, Meda AR, von Wirén N, Soll JR, Philippar K (2007) PIC1, an ancient permease in Arabidopsis chloroplasts, mediates iron transport. Plant Cell 19 (3):986-1006

Eckhardt U, Marques AM, Buckhout TJ (2001) Two iron-regulated cation transporters from tomato complement metal uptake-deficient yeast mutants. Plant Mol Biol 45(4):437-448

Eltayeb AE, Kawano N, Badawi GH, Kaminaka H, Sanekata T, Shibahara T et al. (2007) Overexpression of monodehydroascorbate reductase in transgenic tobacco confers enhanced tolerance to ozone, salt and polyethylene glycol stresses. Planta 225(5):1255-1264

Fagoaga C, Rodrigo I, Conejero V, Hinarejos C, Tuset JJ, Arnau J et al. (2001) Increased tolerance to Phytophthora citrophthora in transgenic orange plants constitutively expressing a tomato pathogenesis related protein PR-5. Mol Breed 7 (2):175-185

Fairbanks DJ, Rytting B (2001) Mendelian controversies: a botanical and historical review. Am J Bot 88(5):737-752

Firbank LG, Attwood S, Eory V, Gadanakis Y, Lynch JM, Sonnino R et al. (2018) Grand challenges in sustainable intensification and ecosystem services. Front Sust Food Syst 2:7

Food Security Information Network (FSIN) Global Report on Food Crises 2020: Joint Analysis for Better Decisions World Food Programme, Rome, Italy (2020)

Frossard E, Bucher M, Mächler F, Mozafar A, Hurrell R (2000) Potential for increasing the content and bioavailability of $\mathrm{Fe}, \mathrm{Zn}$ and $\mathrm{Ca}$ in plants for human nutrition. $J$ Sci Food Agric 80(7):861-879

Gaber A, Yoshimura K, Yamamoto T, Yabuta Y, Takeda T, Miyasaka H et al. (2006) Glutathione peroxidase-like protein of Synechocystis PCC 6803 confers tolerance to oxidative and environmental stresses in transgenic Arabidopsis. Physiol Plant 128(2):251-262

Gao F, Yao H, Zhao H, Zhou J, Luo X, Huang Y et al. (2016) Tartary buckwheat FtMYB10 encodes an R2R3-MYB transcription factor that acts as a novel negative regulator of salt and drought response in transgenic Arabidopsis. Plant Physiol Biochem 109:387-396

Gao S, Zhang H, Tian Y, Li F, Zhang Z, Lu X et al. (2008) Expression of TERF1 in rice regulates expression of stress-responsive genes and enhances tolerance to drought and high-salinity. Plant Cell Rep 27(11):1787-1795

Genc Y, Humphries JM, Lyons GH, Graham RD (2005) Exploiting genotypic variation in plant nutrient accumulation to alleviate micronutrient deficiency in populations. J Trace Elem Med Biol 18(4):319-324

Gilmour SJ, Sebolt AM, Salazar MP, Everard JD, Thomashow MF (2000) Overexpression of the Arabidopsis CBF3 transcriptional activator mimics multiple biochemical changes associated with cold acclimation. Plant Physiol 124(4):1854-1865

Goel D, Singh A, Yadav V, Babbar S, Bansal K (2010) Overexpression of osmotin gene confers tolerance to salt and drought stresses in transgenic tomato (Solanum lycopersicum L.). Protoplasma 245(1):133-141

Goto F, Yoshihara T, Saiki H (2000) Iron accumulation and enhanced growth in transgenic lettuce plants expressing the iron-binding protein ferritin. Theor Appl Genet 100(5):658-664

Graham RD, Welch RM, Bouis HE (2001) Addressing micronutrient malnutrition through enhancing the nutritional quality of staple foods: principles, perspectives and knowledge gaps. Advances in Agronomy 70:77-142. https://doi.org/ 10.1016/S0065-2113(01)70004-1

Graham RD, Welch RM, Saunders DA, Ortiz-Monasterio I, Bouis HE, Bonierbale M et al. (2007) Nutritious subsistence food systems. Adv Agron 92:1-74

Green LS, Rogers EE (2004) FRD3 controls iron localization in Arabidopsis. Plant Physiol 136(1):2523-2531

Gross J, Stein RJ, Fett-Neto AG, Fett JP (2003) Iron homeostasis related genes in rice. Genet Mol Biol 26:477-497

Grotz N, Guerinot ML (2006) Molecular aspects of $\mathrm{Cu}$, Fe and $\mathrm{Zn}$ homeostasis in plants. Biochim et Biophys Acta 1763(7):595-608
Guo W-J, Bundithya W, Goldsbrough PB (2003) Characterization of the Arabidopsis metallothionein gene family: tissue-specific expression and induction during senescence and in response to copper N. Phytol 159(2):369-381

Hao D, Ohme-Takagi M, Sarai A (1998) Unique mode of GCC box recognition by the DNA-binding domain of ethylene-responsive element-binding factor (ERF domain) in plant. J Biol Chem 273(41):26857-26861

Hao Z, Wang X, Zong Y, Wen S, Cheng Y, Li H (2019) Enzymatic activity and functional analysis under multiple abiotic stress conditions of a dehydroascorbate reductase gene derived from Liriodendron Chinense. Environ Exp Bot 167:103850

Hasanuzzaman M, Hossain MA, da Silva JAT, Fujita M (2012) Plant response and tolerance to abiotic oxidative stress: antioxidant defense is a key factor Crop stress and its management: perspectives and strategies. Springer, Dordrecht, 261-315

Haydon MJ, Cobbett CS (2007) Transporters of ligands for essential metal ions in plants. N. Phytologist 174(3):499-506

He L, Yang X, Wang L, Zhu L, Zhou T, Deng J et al. (2013) Molecular cloning and functional characterization of a novel cotton CBL-interacting protein kinase gene (GhCIPK6) reveals its involvement in multiple abiotic stress tolerance in transgenic plants. Biochem Biophys Res Commun 435(2):209-215

He X, Zhang J (2006) Toward a molecular understanding of pleiotropy. Genetics 173 (4):1885-1891

Hodgkin J (2002) Seven types of pleiotropy. Int J Dev Biol 42(3):501-505

Hoffland E, Wei C, Wissuwa M (2006) Organic anion exudation by lowland rice (Oryza sativa L.) at zinc and phosphorus deficiency. Plant Soil 283(1):155-162

Hossain MA, Teixeira da Silva J, Fujita M (2011) Glyoxalase system and reactive oxygen species detoxification system in plant abiotic stress response and tolerance: an intimate relationship. Abiot Stress/book 1:235-266

Hsieh T-H, Lee J-T, Charng Y-Y, Chan M-T (2002) Tomato plants ectopically expressing Arabidopsis CBF1 show enhanced resistance to water deficit stress. Plant Physiol 130(2):618-626

Husaini AM (2014) Challenges of climate change: Omics-based biology of saffron plants and organic agricultural biotechnology for sustainable saffron production. GM Crops Food 5(2):97-105

Husaini AM, Abdin MZ (2008a) Development of transgenic strawberry (Fragaria $x$ ananassa Duch.) plants tolerant to salt stress. Plant Sci 174(4):446-455

Husaini AM, Abdin MZ (2008b) Overexpression of tobacco osmotin gene leads to salt stress tolerance in strawberry (Fragariax ananassa Duch.) plants. Indian J Biotechnol 7:465-471

Husaini AM, Rafiqi AM (2012) Role of osmotin in strawberry improvement. Plant Mol Biol Rep 30(5):1055-1064

Husaini AM, Tuteja N (2013) Biotech crops: Imperative for achieving the Millenium Development Goals and sustainability of agriculture in the climate change era. GM Crops Food 4(1):1-9

Husaini AM, Sohail M (2018) Time to redefine organic agriculture: Can't GM crops be certified as organics? Front Plant Sci 9:423

Husaini AM, Rashid Z, Mir RU, Aquil B (2011) Approaches for gene targeting and targeted gene expression in plants. GM Crops 2(3):150-162

Husaini AM, Kamili AN, Wani M, Teixeira da Silva J, Bhat G (2010) Sustainable saffron (Crocus sativus Kashmirianus) production: technological and policy interventions for Kashmir. Funct Plant Sci Biotechnol 4(2):116-127

Husaini AM, Abdin MZ, Khan S, Xu YW, Aquil S, Anis M (2012) Modifying strawberry for better adaptability to adverse impact of climate change. Curr Sci 102 (12):1660-1673

Husaini AM and Xu YW (2016) Challenges of Climate Change to Strawberry Cultivation: Uncertainty and Beyond. In: Strawberry- Growth, Development and Diseases (Eds. Husaini AM and Neri D), CABI, UK, pp.262-287

Ibrahim S, Saleem B, Rehman N, Zafar SA, Naeem MK, Khan MR (2021) CRISPR/Cas9 mediated disruption of Inositol Pentakisphosphate 2-Kinase 1 (TalPK1) reduces phytic acid and improves iron and zinc accumulation in wheat grains. J Adv Res. https://doi.org/10.1016/j.jare.2021.07.006

Ishimaru Y, Suzuki M, Kobayashi T, Takahashi M, Nakanishi H, Mori S et al. (2005) OsZIP4, a novel zinc-regulated zinc transporter in rice. J Exp Bot 56 (422):3207-3214

Ishimaru Y, Suzuki M, Tsukamoto T, Suzuki K, Nakazono M, Kobayashi T et al. (2006) Rice plants take up iron as an Fe3+-phytosiderophore and as Fe2+. Plant J 45 (3):335-346

Ismail AM, Heuer S, Thomson MJ, Wissuwa M (2007) Genetic and genomic approaches to develop rice germplasm for problem soils. Plant Mol Biol 65(4):547-570

Ito Y, Katsura K, Maruyama K, Taji T, Kobayashi M, Seki M et al. (2006) Functional analysis of rice DREB1/CBF-type transcription factors involved in coldresponsive gene expression in transgenic rice. Plant Cell Physiol 47(1):141-153

Jaglo-Ottosen KR, Gilmour SJ, Zarka DG, Schabenberger O, Thomashow MF (1998) Arabidopsis CBF1 overexpression induces COR genes and enhances freezing tolerance. Science 280(5360):104-106 
Jean ML, Schikora A, Mari S, Briat JF, Curie C (2005) A loss-of-function mutation in AtYSL1 reveals its role in iron and nicotianamine seed loading. Plant $J 44$ (5):769-782

Jia H, Hao L, Guo X, Liu S, Yan Y, Guo X (2016) A Raf-like MAPKKK gene, GhRaf19, negatively regulates tolerance to drought and salt and positively regulates resistance to cold stress by modulating reactive oxygen species in cotton. Plant Sci 252:267-281

Jung C, Seo JS, Han SW, Koo YJ, Kim CH, Song SI et al. (2008) Overexpression of AtMYB44 enhances stomatal closure to confer abiotic stress tolerance in transgenic Arabidopsis. Plant Physiol 146(2):623-635

Kapoor D, Singh S, Kumar V, Romero R, Prasad R, Singh J (2019) Antioxidant enzymes regulation in plants in reference to reactive oxygen species (ROS) and reactive nitrogen species (RNS). Plant Gene 19:100182

Kasuga M, Miura S, Shinozaki K, Yamaguchi-Shinozaki K (2004) A combination of the Arabidopsis DREB1A gene and stress-inducible rd29A promoter improved drought-and low-temperature stress tolerance in tobacco by gene transfer. Plant Cell Physiol 45(3):346-350

Kasuga M, Liu Q, Miura S, Yamaguchi-Shinozaki K, Shinozaki K (1999) Improving plant drought, salt, and freezing tolerance by gene transfer of a single stressinducible transcription factor. Nat Biotechnol 17(3):287-291

Kaur A, Reddy MS, Pati PK, Kumar A (2020) Over-expression of osmotin (OsmWS) gene of Withania somnifera in potato cultivar 'Kufri Chipsona 1'imparts resistance to Alternaria solani. Plant Cell Tiss Org 142:131-142

Kim SA, Punshon T, Lanzirotti A, Li L, Alonso JM, Ecker JR et al. (2006) Localization of iron in Arabidopsis seed requires the vacuolar membrane transporter VIT1. Science 314(5803):1295-1298

Kim Y-H, Hong JK, Kim HS, Kwak S-S (2021) Overexpression of the sweetpotato peroxidase gene swpa4 enhances tolerance to methyl viologen-mediated oxidative stress and dehydration in Arabidopsis thaliana. J Plant Biochem Biotechnol 30(1):215-220

Kim Y-H, Kim CY, Song W-K, Park D-S, Kwon S-Y, Lee H-S et al. (2008) Overexpression of sweetpotato swpa4 peroxidase results in increased hydrogen peroxide production and enhances stress tolerance in tobacco. Planta 227(4):867-881

Kitashiba H, Ishizaka T, Isuzugawa K, Nishimura K, Suzuki T (2004) Expression of a sweet cherry DREB1/CBF ortholog in Arabidopsis confers salt and freezing tolerance. J Plant Physiol 161(10):1171-1176

Koike S, Inoue H, Mizuno D, Takahashi M, Nakanishi H, Mori S et al. (2004) OsYSL2 is a rice metal-nicotianamine transporter that is regulated by iron and expressed in the phloem. Plant J 39(3):415-424

Kovtun Y, Chiu W-L, Tena G, Sheen J (2000) Functional analysis of oxidative stressactivated mitogen-activated protein kinase cascade in plants. Proc Natl Acad Sci 97(6):2940-2945

Krüger C, Berkowitz O, Stephan UW, Hell RD (2002) A metal-binding member of the late embryogenesis abundant protein family transports iron in the phloem Ofricinus communis L. J Biol Chem 277(28):25062-25069

Kumar SA, Kumari PH, Jawahar G, Prashanth S, Suravajhala P, Katam R et al. (2016) Beyond just being foot soldiers-osmotin like protein (OLP) and chitinase (Chi11) genes act as sentinels to confront salt, drought, and fungal stress tolerance in tomato. Environ Exp Bot 132:53-65

Kwon S-Y, Choi S-M, Ahn Y-O, Lee H-S, Lee H-B, Park Y-M et al. (2003) Enhanced stress-tolerance of transgenic tobacco plants expressing a human dehydroascorbate reductase gene. J Plant Physiol 160(4):347-353

Lanquar V, Lelièvre F, Bolte S, Hamès C, Alcon C, Neumann D et al. (2005) Mobilization of vacuolar iron by AtNRAMP3 and AtNRAMP4 is essential for seed germination on low iron. EMBO J 24(23):4041-4051

Le $\Pi$, Williams B, Mundree SG (2018) An osmotin from the resurrection plant Tripogon loliiformis (TIOsm) confers tolerance to multiple abiotic stresses in transgenic rice. Physiol Plant 162(1):13-34

Lee S-H, Ahsan N, Lee K-W, Kim D-H, Lee D-G, Kwak S-S et al. (2007) Simultaneous overexpression of both CuZn superoxide dismutase and ascorbate peroxidase in transgenic tall fescue plants confers increased tolerance to a wide range of abiotic stresses. J Plant Physiol 164(12):1626-1638

Li N, Han X, Feng D, Yuan D, Huang L-J (2019) Signaling crosstalk between salicylic acid and ethylene/jasmonate in plant defense: do we understand what they are whispering? Int J Mol Sci 20(3):671

Li R, Wu N, Fan Y, Song B (1999) Transgenic potato plants expressing osmotin gene inhibits fungal development in inoculated leaves. Chin J Biotechnol 15(2):71-75

Liang H, Lu Y, Liu H, Wang F, Xin Z, Zhang Z (2008) A novel activator-type ERF of Thinopyrum intermedium, TiERF1, positively regulates defence responses. J Exp Bot 59(11):3111-3120

Liao X, Lv C, Zhang X, Masuda T, Li M, Zhao G (2012) A novel strategy of natural plant ferritin to protect DNA from oxidative damage during iron oxidation. Free Radic Biol Med 53(2):375-382
Liu D, Raghothama KG, Hasegawa PM, Bressan RA (1994) Osmotin overexpression in potato delays development of disease symptoms. Proc Natl Acad Sci 91 (5):1888-1892

Liu Q, Kasuga M, Sakuma Y, Abe H, Miura S, Yamaguchi-Shinozaki K et al. (1998) Two transcription factors, DREB1 and DREB2, with an EREBP/AP2 DNA binding domain separate two cellular signal transduction pathways in drought-and lowtemperature-responsive gene expression, respectively, in Arabidopsis. Plant Cell 10(8):1391-1406

Long L, Gao W, Xu L, Liu M, Luo X, He X et al. (2014) GbMPK3, a mitogen-activated protein kinase from cotton, enhances drought and oxidative stress tolerance in tobacco. Plant Cell, Tissue Organ Cult 116(2):153-162

Lopez-Millan A-F, Ellis DR, Grusak MA (2004) Identification and characterization of several new members of the ZIP family of metal ion transporters in Medicago truncatula. Plant Mol Biol 54(4):583-596

Lucca P, Hurrell R, Potrykus I (2001) Genetic engineering approaches to improve the bioavailability and the level of iron in rice grains. Theor Appl Genet 102 (2):392-397

Luo M, Li H, Chakraborty S, Morbitzer R, Rinaldo A, Upadhyaya N et al. (2019) Efficient TALEN-mediated gene editing in wheat. Plant Biotechnol J 17 (11):2026-2028

Ma J-T, Yin C-C, Zhou M-L, Wang Z-L, Wu Y-M (2015) A novel DREB transcription factor from Halimodendron halodendron leads to enhance drought and salt tolerance in Arabidopsis. Biol Plant 59(1):74-82

Mackintosh CA, Lewis J, Radmer LE, Shin S, Heinen SJ, Smith LA et al. (2007) Overexpression of defense response genes in transgenic wheat enhances resistance to Fusarium head blight. Plant Cell Rep 26(4):479-488

Mallikarjuna G, Mallikarjuna K, Reddy M, Kaul T (2011) Expression of OsDREB2A transcription factor confers enhanced dehydration and salt stress tolerance in rice (Oryza sativa L.). Biotechnol Lett 33(8):1689-1697

Matuschek E, Towo E, Svanberg U (2001) Oxidation of polyphenols in phytatereduced high-tannin cereals: effect on different phenolic groups and on in vitro accessible iron. J Agric Food Chem 49(11):5630-5638

McCouch S, Baute GJ, Bradeen J, Bramel P, Bretting PK, Buckler E et al. (2013) Feeding the future. Nature 499(7456):23-24

Mira H, Martínez-García F, Peñarrubia L (2001) Evidence for the plant-specific intercellular transport of the Arabidopsis copper chaperone $\mathrm{CCH}$. Plant J 25 (5):521-528

Mukherjee I, Campbell NH, Ash JS, Connolly EL (2006) Expression profiling of the Arabidopsis ferric chelate reductase (FRO) gene family reveals differential regulation by iron and copper. Planta 223(6):1178-1190

Müller M, Munné-Bosch S (2015) Ethylene response factors: a key regulatory hub in hormone and stress signaling. Plant Physiol 169(1):32-41

Murray-Kolb LE, Takaiwa F, Goto F, Yoshihara T, Theil EC, Beard JL (2002) Transgenic rice is a source of iron for iron-depleted rats. J Nutr 132(5):957-960

Noori SS, Sokhansanj A (2008) Wheat plants containing an osmotin gene show enhanced ability to produce roots at high $\mathrm{NaCl}$ concentration. Russian J Plant Physiol 55(2):256-258

Oh SJ, Kwon CW, Choi DW, Song SI, Kim JK (2007) Expression of barley HvCBF4 enhances tolerance to abiotic stress in transgenic rice. Plant Biotechnol J 5 (5):646-656

Ohme-Takagi M, Shinshi H (1995) Ethylene-inducible DNA binding proteins that interact with an ethylene-responsive element. Plant Cell 7(2):173-182

Ouyang B, Chen Y, Li H, Qian C, Huang S, Ye Z (2005) Transformation of tomatoes with osmotin and chitinase genes and their resistance to Fusarium wilt. J Horticultural Sci Biotechnol 80(5):517-522

Paaby AB, Rockman MV (2013) The many faces of pleiotropy. Trends Genet 29 (2):66-73

Palmgren MG, Clemens S, Williams LE, Krämer U, Borg S, Schjørring JK et al. (2008) Zinc biofortification of cereals: problems and solutions. Trends Plant Sci 13 (9):464-473

Pan C, Wu X, Markel K, Malzahn AA, Kundagrami N, Sretenovic S et al. (2021) CRISPRAct3. 0 for highly efficient multiplexed gene activation in plants. Nat Plants 7 (7):1-12

Pan J, Zhang M, Kong X, Xing X, Liu Y, Zhou Y et al. (2012a) ZmMPK17, a novel maize group D MAP kinase gene, is involved in multiple stress responses. Planta 235 (4):661-676

Pan Y, Seymour GB, Lu C, Hu Z, Chen X, Chen G (2012b) An ethylene response factor (ERF5) promoting adaptation to drought and salt tolerance in tomato. Plant Cell Rep. 31(2):349-360

Park JM, Park C-J, Lee S-B, Ham B-K, Shin R, Paek K-H (2001) Overexpression of the tobacco Tsi1 gene encoding an EREBP/AP2-type transcription factor enhances resistance against pathogen attack and osmotic stress in tobacco. Plant Cell 13 (5):1035-1046 
Parkhi V, Kumar V, Sunilkumar G, Campbell LM, Singh NK, Rathore KS (2009) Expression of apoplastically secreted tobacco osmotin in cotton confers drought tolerance. Mol Breed 23(4):625-639

Pavlović S, Savić J, Milojević J, Vinterhalter B, Girek Z, Adžić S et al. (2020) Introduction of the Nicotiana protein kinase (NPK1) gene by combining Agrobacterium-mediated transformation and recurrent somatic embryogenesis to enhance salt tolerance in cauliflower. Plant Cell, Tissue Organ Cult 143 (3):635-651

Pence NS, Larsen PB, Ebbs SD, Letham DL, Lasat MM, Garvin DF et al. (2000) The molecular physiology of heavy metal transport in the $\mathrm{Zn} / \mathrm{Cd}$ hyperaccumulator Thlaspi caerulescens. Proc Natl Acad Sci 97(9):4956-4960

Petit J-M, Briat J-F, Lobréaux S (2001) Structure and differential expression of the four members of the Arabidopsis thaliana ferritin gene family. Biochem J 359 (3):575-582

Pfeiffer WH, McClafferty B (2007) HarvestPlus: breeding crops for better nutrition Crop Sci 47:S-88-S-105

Potrykus I (2003) Nutritionally enhanced rice to combat malnutrition disorders of the poor. Nutr Rev 61(suppl_6):S101-S104

Prashanth S, Sadhasivam V, Parida A (2008) Over expression of cytosolic copper/zinc superoxide dismutase from a mangrove plant Avicennia marina in indica rice var Pusa Basmati-1 confers abiotic stress tolerance. Transgenic Res. 17 (2):281-291

Puig S, Andrés-Colás N, García-Molina A, Penarrubia L (2007) Copper and iron homeostasis in Arabidopsis: responses to metal deficiencies, interactions and biotechnological applications. Plant, Cell Environ 30(3):271-290

Qin F, Kakimoto M, Sakuma Y, Maruyama K, Osakabe Y, Tran LSP et al. (2007) Regulation and functional analysis of ZmDREB2A in response to drought and heat stresses in Zea mays L. Plant J 50(1):54-69

Raghothama K, Liu D, Nelson DE, Hasegawa PM, Bressan RA (1993) Analysis of an osmotically regulated pathogenesis-related osmotin gene promoter. Plant $\mathrm{Mol}$ Biol 23(6):1117-1128

Ramireddy E, Hosseini SA, Eggert K, Gillandt S, Gnad H, von Wirén N et al. (2018) Root engineering in barley: increasing cytokinin degradation produces a larger root system, mineral enrichment in the shoot and improved drought tolerance. Plant Physiol 177(3):1078-1095

Ramos MV, de Oliveira RS, Pereira HM, Moreno FB, Lobo MD, Rebelo LM et al. (2015) Crystal structure of an antifungal osmotin-like protein from Calotropis procera and its effects on Fusarium solani spores, as revealed by atomic force microscopy: Insights into the mechanism of action. Phytochemistry 119:5-18

Raney T, Pingali P (2007) Sowing a gene revolution. Sci Am 297(3):104-111

Ray DK, Mueller ND, West PC, Foley JA (2013) Yield trends are insufficient to double global crop production by 2050. PloS One 8(6):e66428

Reidmiller DR, Avery CW, Easterling DR, Kunkel KE, Lewis KL, Maycock TK et al. (2018) Impacts, risks, and adaptation in the United States: Fourth national climate assessment, volume II. (US Global Change Research Program, 2018)10.7930/ NCA4.2018

Riechmann JL, Meyerowitz EM (1998) The AP2/EREBP family of plant transcription factors. Biol Chem 379:633-646

Robinson NJ, Procter CM, Connolly EL, Guerinot ML (1999) A ferric-chelate reductase for iron uptake from soils. Nature 397(6721):694-697

Roca Paixao JF, Gillet FX, Ribeiro TP, Bournaud C, Lourenco-Tessutti IT, Noriega DD et al. (2019) Improved drought stress tolerance in Arabidopsis by CRISPR/dCas9 fusion with a Histone AcetylTransferase. Sci Rep 9(1):8080

Saijo Y, Hata S, Kyozuka J, Shimamoto K, Izui K (2000) Over-expression of a single Ca2 +-dependent protein kinase confers both cold and salt/drought tolerance on rice plants. Plant J 23(3):319-327

Sakuma Y, Liu Q, Dubouzet JG, Abe H, Shinozaki K, Yamaguchi-Shinozaki K (2002) DNA-binding specificity of the ERF/AP2 domain of Arabidopsis DREBs, transcription factors involved in dehydration-and cold-inducible gene expression. Biochem Biophys Res Commun 290(3):998-1009

Sakuma Y, Maruyama K, Osakabe Y, Qin F, Seki M, Shinozaki K et al. (2006) Functional analysis of an Arabidopsis transcription factor, DREB2A, involved in droughtresponsive gene expression. Plant Cell 18(5):1292-1309

Schaaf G, Ludewig U, Erenoglu BE, Mori S, Kitahara T, Von Wirén N (2004) ZmYS1 functions as a proton-coupled symporter for phytosiderophore-and nicotianamine-chelated metals. J Biol Chem 279(10):9091-9096

Scovel G, Ben-Meir H, Zuker A, Shklarman E, Ovadis M, Neta-Sharir I et al. (2000). Genetic engineering of agronomic and ornamental traits in carnation. In IV International Symposium on In Vitro Culture and Horticultural Breeding 560, pp 91-94

Seo YJ, Park J-B, Cho Y-J, Jung C, Seo HS, Park S-K et al. (2010) Overexpression of the ethylene-responsive factor gene BrERF4 from Brassica rapa increases tolerance to salt and drought in Arabidopsis plants. Molecules Cells 30 (3):271-277
Sharoni AM, Nuruzzaman M, Satoh K, Shimizu T, Kondoh H, Sasaya T et al. (2011) Gene structures, classification and expression models of the AP2/EREBP transcription factor family in rice. Plant Cell Physiol 52(2):344-360

Shewry PR, Ward JL (2012) Exploiting genetic variation to improve wheat composition for the prevention of chronic diseases. Food Energy Security 1(1):47-60

Shi J, Wang H, Hazebroek J, Ertl DS, Harp T (2005) The maize low-phytic acid 3 encodes a myo-inositol kinase that plays a role in phytic acid biosynthesis in developing seeds. Plant J 42(5):708-719

Shi J, An H-L, Zhang L, Gao Z, Guo X-Q (2010) GhMPK7, a novel multiple stressresponsive cotton group $C$ MAPK gene, has a role in broad spectrum disease resistance and plant development. Plant Mol Biol 74(1-2):1-17

Shou H, Bordallo P, Wang K (2004) Expression of the Nicotiana protein kinase (NPK1) enhanced drought tolerance in transgenic maize. J Exp Bot 55(399):1013-1019

Shuman LM (1998) Micronutrient fertilizers. J Crop Prod 1(2):165-195

Silva KJP, Brunings A, Peres NA, Mou Z, Folta KM (2015) The Arabidopsis NPR1 gene confers broad-spectrum disease resistance in strawberry. Transgenic Res 24 (4):693-704

Singh B, Dheeravathu SN, Usha K (2010) Micronutrient deficiency: A global challenge and physiological approach to improve grain productivity under low zinc availability. Plant Stress 4:76-93

Singh NK, Handa AK, Hasegawa PM, Bressan RA (1985) Proteins associated with adaptation of cultured tobacco cells to $\mathrm{NaCl}$. Plant Physiol 79(1):126-137

Singh NK, Bracker CA, Hasegawa PM, Handa AK, Buckel S, Hermodson MA et al. (1987) Characterization of osmotin: a thaumatin-like protein associated with osmotic adaptation in plant cells. Plant Physiol 85(2):529-536

Sokhansanj A, Noori SS, Niknam V (2006) Comparison of bacterial and plant genes participating in proline biosynthesis with osmotin gene, with respect to enhancing salinity tolerance of transgenic tobacco plants. Russian J Plant Physiol 53(1):110-115

Solovieff N, Cotsapas C, Lee PH, Purcell SM, Smoller JW (2013) Pleiotropy in complex traits: challenges and strategies. Nat Rev Genet 14(7):483-495

Song Z-Z, Yang S-Y, Zuo J, Su Y-H (2014) Over-expression of ApKUP3 enhances potassium nutrition and drought tolerance in transgenic rice. Biol Plant 58 (4):649-658

Sripriya R, Parameswari C, Veluthambi K (2017) Enhancement of sheath blight tolerance in transgenic rice by combined expression of tobacco osmotin (ap24) and rice chitinase (chi11) genes. Vitr Cell Dev Biol-Plant 53(1):12-21

Stearns FW (2010) One hundred years of pleiotropy: a retrospective. Genetics 186 (3):767-773

Sultana S, Khew C-Y, Morshed MM, Namasivayam P, Napis S, Ho C-L (2012) Overexpression of monodehydroascorbate reductase from a mangrove plant (AeMDHAR) confers salt tolerance on rice. J Plant Physiol 169(3):311-318

Sun Y, Wang C, Chen HY, Ruan H (2020) Response of plants to water stress: a metaanalysis. Front Plant Sci 11:978

Suzuki M, Takahashi M, Tsukamoto T, Watanabe S, Matsuhashi S, Yazaki J et al. (2006) Biosynthesis and secretion of mugineic acid family phytosiderophores in zincdeficient barley. Plant J 48(1):85-97

Takahashi M, Nakanishi H, Kawasaki S, Nishizawa NK, Mori S (2001) Enhanced tolerance of rice to low iron availability in alkaline soils using barley nicotianamine aminotransferase genes. Nat Biotechnol 19(5):466-469

Tang G, Qin J, Dolnikowski GG, Russell RM, Grusak MA (2009) Golden Rice is an effective source of vitamin A. Am J Clin Nutr 89(6):1776-1783

Tang W, Charles TM, Newton RJ (2005) Overexpression of the pepper transcription factor CaPF1 in transgenic Virginia pine (Pinus virginiana Mill.) confers multiple stress tolerance and enhances organ growth. Plant Mol Biol 59(4):603-617

Tauris B, Borg S, Gregersen PL, Holm PB (2009) A roadmap for zinc trafficking in the developing barley grain based on laser capture microdissection and gene expression profiling. J Exp Bot 60(4):1333-1347

Teige M, Scheikl E, Eulgem T, Dóczi R, Ichimura K, Shinozaki K et al. (2004) The MKK2 pathway mediates cold and salt stress signaling in Arabidopsis. Mol Cell 15 (1):141-152

Trujillo L, Sotolongo M, Menendez C, Ochogavia M, Coll Y, Hernandez I et al. (2008) SodERF3, a novel sugarcane ethylene responsive factor (ERF), enhances salt and drought tolerance when overexpressed in tobacco plants. Plant Cell Physiol 49 (4):512-525

Ushimaru T, Nakagawa T, Fujioka Y, Daicho K, Naito M, Yamauchi Y et al. (2006) Transgenic Arabidopsis plants expressing the rice dehydroascorbate reductase gene are resistant to salt stress. J Plant Physiol 163(11):1179-1184

Vasconcelos M, Datta K, Oliva N, Khalekuzzaman M, Torrizo L, Krishnan S et al. (2003) Enhanced iron and zinc accumulation in transgenic rice with the ferritin gene. Plant Sci 164(3):371-378

Vert G, Grotz N, Dédaldéchamp F, Gaymard F, Guerinot ML, Briat J-F et al. (2002) IRT1, an Arabidopsis transporter essential for iron uptake from the soil and for plant growth. Plant Cell 14(6):1223-1233 
Viktorova J, Krasny L, Kamlar M, Novakova M, Mackova M, Macek T (2012) Osmotin, a pathogenesis-related protein. Curr Protein Pept Sci 13(7):672-681

Wagner GP, Zhang J (2011) The pleiotropic structure of the genotype-phenotype map: the evolvability of complex organisms. Nat Rev Genet 12(3):204-213

Wang C-T, Ru J-N, Liu Y-W, Li M, Zhao D, Yang J-F et al. (2018) Maize WRKY transcription factor ZmWRKY106 confers drought and heat tolerance in transgenic plants. Int J Mol Sci 19(10):3046

Wang H, Wang H, Shao H, Tang X (2016) Recent advances in utilizing transcription factors to improve plant abiotic stress tolerance by transgenic technology. Front Plant Sci 7:67

Wang $\mathrm{H}$, Huang Z, Chen Q, Zhang Z, Zhang H, Wu Y et al. (2004) Ectopic overexpression of tomato JERF3 in tobacco activates downstream gene expression and enhances salt tolerance. Plant Mol Biol 55(2):183-192

Wang L, Qin L, Liu W, Zhang D, Wang Y (2014) A novel ethylene-responsive factor from Tamarix hispida, ThERF1, is a GCC-box-and DRE-motif binding protein that negatively modulates abiotic stress tolerance in Arabidopsis. Physiol Plant 152 (1):84-97

Wang Y, Wisniewski M, Meilan R, Cui M, Webb R, Fuchigami L (2005) Overexpression of cytosolic ascorbate peroxidase in tomato confers tolerance to chilling and salt stress. J Am Soc Horticultural Sci 130(2):167-173

Wang Y, Wisniewski M, Meilan R, Cui M, Fuchigami L (2006) Transgenic tomato (Lycopersicon esculentum) overexpressing cAPX exhibits enhanced tolerance to UV-B and heat stress.

Waters BM, Grusak MA (2008) Whole-plant mineral partitioning throughout the life cycle in Arabidopsis thaliana ecotypes Columbia, Landsberg erecta, Cape Verde Islands, and the mutant line ysl1ys|3. N. Phytologist 177(2):389-405

White PJ, Broadley MR (2005) Biofortifying crops with essential mineral elements. Trends Plant Sci 10(12):586-593

White PJ, Broadley MR (2009) Biofortification of crops with seven mineral elements often lacking in human diets-iron, zinc, copper, calcium, magnesium, selenium and iodine. N. Phytologist 182(1):49-84

White PJ, Bowen HC, Demidchik V, Nichols C, Davies JM (2002) Genes for calciumpermeable channels in the plasma membrane of plant root cells. Biochim et Biophys Acta 1564(2):299-309

Wintz H, Fox T, Wu Y-Y, Feng V, Chen W, Chang H-S et al. (2003) Expression profiles of Arabidopsis thaliana in mineral deficiencies reveal novel transporters involved in metal homeostasis. J Biol Chem 278(48):47644-47653

von Wirén N, Marschner H, Römheld V (1995) Uptake kinetics of ironphytosiderophores in two maize genotypes differing in iron efficiency. Physiol Plant 93(4):611-616

von Wirén N, Marschner H, Romheld V (1996) Roots of iron-efficient maize also absorb phytosiderophore-chelated zinc. Plant Physiol 111(4):1119-1125

Wirth J, Poletti S, Aeschlimann B, Yakandawala N, Drosse B, Osorio S et al. (2009) Rice endosperm iron biofortification by targeted and synergistic action of nicotianamine synthase and ferritin. Plant Biotechnol J 7(7):631-644

Wong CKE, Cobbett CS (2009) HMA P-type ATPases are the major mechanism for rootto-shoot Cd translocation in Arabidopsis thaliana. N. Phytologist 181(1):71-78

Wu H, Li L, Du J, Yuan Y, Cheng X, Ling H-Q (2005) Molecular and biochemical characterization of the Fe (III) chelate reductase gene family in Arabidopsis thaliana. Plant Cell Physiol 46(9):1505-1514

Wu L, Zhang Z, Zhang H, Wang X-C, Huang R (2008) Transcriptional modulation of ethylene response factor protein JERF3 in the oxidative stress response enhances tolerance of tobacco seedlings to salt, drought, and freezing. Plant Physiol 148(4):1953-1963

Xianghong Li et al. Cas-CLOVER ${ }^{T \text { m: }}$ A High-Fidelity Genome Editing System for Safe and Efficient Modification of Cells for Immunotherapy. 2018 Precision CRISPR Congress Poster Presentation, Boston, MA

Xiong L, Yang Y (2003) Disease resistance and abiotic stress tolerance in rice are inversely modulated by an abscisic acid-inducible mitogen-activated protein kinase. Plant Cell 15(3):745-759

Xu J, Yang J, Duan X, Jiang Y, Zhang P (2014) Increased expression of native cytosolic $\mathrm{Cu} / \mathrm{Zn}$ superoxide dismutase and ascorbate peroxidase improves tolerance to oxidative and chilling stresses in cassava (Manihot esculenta Crantz). BMC Plant Biol 14(1):1-14

Xu Z-S, Xia L-Q, Chen M, Cheng X-G, Zhang R-Y, Li L-C et al. (2007) Isolation and molecular characterization of the Triticum aestivum $L$. ethylene-responsive factor 1 (TaERF1) that increases multiple stress tolerance. Plant Mol Biol 65 (6):719-732
Xue X, Cao Z, Zhang X, Wang Y, Zhang Y, Chen Z et al. (2016) Overexpression of OsOSM1 enhances resistance to rice sheath blight. Plant Dis 100(8):1634-1642

Yan H, Jia H, Chen X, Hao L, An H, Guo X (2014) The cotton WRKY transcription factor GhWRKY17 functions in drought and salt stress in transgenic Nicotiana benthamiana through $A B A$ signaling and the modulation of reactive oxygen species production. Plant Cell Physiol 55(12):2060-2076

Yang R, Liu J, Lin Z, Sun W, Wu Z, Hu H et al. (2018) ERF transcription factors involved in salt response in tomato. Plant Growth Regul 84(3):573-582

Ye X, Al-Babili S, Klöti A, Zhang J, Lucca P, Beyer P et al. (2000) Engineering the provitamin A ( $\beta$-carotene) biosynthetic pathway into (carotenoid-free) rice endosperm. Science 287(5451):303-305

Yin L, Mano Jl, Tanaka K, Wang S, Zhang M, Deng X et al. (2017) High level of reduced glutathione contributes to detoxification of lipid peroxide-derived reactive carbonyl species in transgenic Arabidopsis overexpressing glutathione reductase under aluminum stress. Physiol Plant 161(2):211-223

Ying Z, Shuli S, Wei S, Yan Z, Jun Z, Weiwei R, Chuang Z (2017) Overexpression of soybean GmERF9 enhances the tolerance to drought and cold in the transgenic tobacco. Plant Cell Tissue and Organ Culture (PCTOC) 128(3):607-618. https:// doi.org/10.1007/s11240-016-1137-8

Yoshimura K, Miyao K, Gaber A, Takeda T, Kanaboshi H, Miyasaka H et al. (2004) Enhancement of stress tolerance in transgenic tobacco plants overexpressing Chlamydomonas glutathione peroxidase in chloroplasts or cytosol. Plant J 37 (1):21-33

Youm JW, Jeon JH, Choi D, Yi SY, Joung H, Kim HS (2008) Ectopic expression of pepper CaPF1 in potato enhances multiple stresses tolerance and delays initiation of in vitro tuberization. Planta 228(4):701-708

Zafar SA, Zaidi SS-E-A, Gaba Y, Singla-Pareek SL, Dhankher OP, Li X et al. (2020) Engineering abiotic stress tolerance via CRISPR/Cas-mediated genome editing. J Exp Bot 71(2):470-479

Zeigler RS (2007) Rice and the millennium development goals: the International Rice Research Institute's strategic plan 2007-2015. Paddy and Water Environment 5 (2):67-71

Zhang G, Chen M, Li L, Xu Z, Chen X, Guo J et al. (2009) Overexpression of the soybean GmERF3 gene, an AP2/ERF type transcription factor for increased tolerances to salt, drought, and diseases in transgenic tobacco. J Exp Bot 60 (13):3781-3796

Zhang L, Sun L, Zhang L, Qiu H, Liu C, Wang A et al. (2017) A Cu/Zn superoxide dismutase gene from Saussurea involucrata Kar. \& Kir., SiCSD, enhances drought, cold, and oxidative stress in transgenic tobacco. Can J Plant Sci 97 (5):816-826

Zhang X, Liu S, Takano T (2008) Two cysteine proteinase inhibitors from Arabidopsis thaliana, AtCYSa and AtCYSb, increasing the salt, drought, oxidation and cold tolerance. Plant Mol Biol 68(1):131-143

Zhu B, Chen TH, Li PH (1993) Expression of an ABA-responsive osmotin-like gene during the induction of freezing tolerance in Solanum commersonii. Plant Mol Biol 21(4):729-735

\section{ACKNOWLEDGEMENTS}

AMH is grateful to Ms. Asma Khurshid for the help in collecting relevant literature for the manuscript.

\section{COMPETING INTERESTS}

The author declares no competing interest.

\section{ADDITIONAL INFORMATION}

Correspondence and requests for materials should be addressed to Amjad $M$. Husaini.

Reprints and permission information is available at http://www.nature.com/ reprints

Publisher's note Springer Nature remains neutral with regard to jurisdictional claims in published maps and institutional affiliations. 